Supporting Information for

\title{
A multi-platform inversion estimation of statewide and regional methane emissions in California during 2014-2016
}

Yu Yan Cui ${ }^{1, *}$, Abhilash Vijayan ${ }^{1}$, Matthias Falk ${ }^{1}$, Ying-Kuang Hsuㄹ, Dazhong Yin ${ }^{1}$, Xue Meng Chen $^{1}$, Zhan Zhao ${ }^{1}$, Jeremy Avise ${ }^{1,2}$, Yanju Chen ${ }^{1}$, Kristal Verhulst ${ }^{3}$, Riley Duren ${ }^{3}$, Vineet Yadav ${ }^{3}$, Charles Miller ${ }^{3}$, Ray Weiss ${ }^{4}$, Ralph Keeling ${ }^{4}$, Jooil Kim ${ }^{4}$, Laura T. Iraci ${ }^{5}$, Tomoaki Tanaka ${ }^{5,6}$, Matthew S. Johnson ${ }^{5}$, Eric A. Kort ${ }^{7}$, Laura Bianco ${ }^{8,9}$, Marc L. Fischer ${ }^{10}$, Kenneth Stroud ${ }^{1}$, Jorn Herner ${ }^{1}$, Bart Croes $^{1}$

1. California Air Resources Board, 1001 I Street, Sacramento, California, USA

2. Department of Civil and Environmental Engineering, Washington State University, Pullman, Washington, USA

3. NASA Jet Propulsion Laboratory, California Institute of Technology, Pasadena, California, USA

4. Scripps Institution of Oceanography, University of California, San Diego, La Jolla, California, USA

5. Earth Science Division, NASA Ames Research Center, Moffett Field, California, USA

6. Japan Weather Association, Tokyo, Japan

7. Department of Physics, University of Michigan, Ann Arbor, Michigan, USA

8. Physical Sciences Division, NOAA Earth System Research Laboratory, Boulder, Colorado, USA

9. The Cooperative Institute for Research in Environmental Sciences, University of Colorado Boulder, Boulder, Colorado, USA

10. Lawrence Berkeley National Laboratory, Berkeley, California, USA

This document contains supplemental text, tables, and figures. Some of tables and figures mentioned here are referenced directly from the main text.

number of pages: 38

number of figures: 13

number of tables: 13 


\section{Contents}

Previous top-down studies.............................................................S-4

Table S-1: Statewide $\mathrm{CH}_{4}$ emission estimates from the previous top-down studies

Table S-2: Regional $\mathrm{CH}_{4}$ emission estimates from the previous top-down studies

Information of Sites. .S-6

Table S-3: Information for Sites Used in the Study during 2014-2016

CARB Statewide GHG Monitoring Network.

Table S-4: Information for three models of Picarro Cavity Ring down Spectrometer (CRDS) instruments

Table S-5: Best constrained spatial resolution for four sub-regions in California

WRF configuration

FLEXPART-WRF .S-9

Table S-6: Footprint values for each composite dataset in each region (unit: $\mathrm{s} \mathrm{m}^{2} / \mu \mathrm{g}$ )

Figure S-1: shows the sensitivity maps (i.e. "footprint") of the receptors in the study to the surface fluxes for 2014-2016

Inverse modeling framework. $. \mathrm{S}-10$

Table S-7: Information for parameters in the inverse modeling setup

PBLH evaluation. S-12

Figure S-2: A map of PBLH retrieval locations, which are used to evaluate WRF PBLH performances for 2014-2016

Figure S-3: Planetary Boulder Layer Heights (PBLH) simulated by WRF in the work are compared with the measurement-determined values from different observation platforms, during the year of 2014-2016. The mean biases (unit: $\mathrm{m}$ above ground level) are shown as well as the values in the brackets representing the absolute values of the ratio (\%) of the mean biases to the measurement-determined PBLHs on average

Prior inventory $. \mathrm{S}-17$

Table S-8: Information of 16 inventories

Table S-9: Statewide $\mathrm{CH}_{4}$ emission estimates in $\mathrm{Tg} / \mathrm{yr}$ by sector for three prior inventories Figure S-4: Two prior inventories (CALGEM version 3 and EPA-GHGI, unit: $\mu \mathrm{g} \mathrm{m}^{-2} \mathrm{~s}^{-1}$ ) used in the inversion estimates

Figure S-5: Comparisons of measured and simulated $\mathrm{CH}_{4}$ mixing ratios using the two prior inventories, which are CALGEM and EPA-GHGI shown in Figure S2. The coefficient of determination $\left(\mathrm{R}^{2}\right)$ and mean biases (unit: $\mathrm{ppb}$ ) are shown

Figure S-6: Comparisons of measured and simulated $\mathrm{CH}_{4}$ mixing ratios during 2014-2016 based on CALGEM, EPA-GHGI, and 14 different hybrid inventories listed in Table S5. The coefficient of determination $\left(\mathrm{R}^{2}\right)$ and mean biases are shown. Comparison \#8 corresponding to the highest $\mathrm{R}^{2}$ is chosen as the one prior inventory to be used in the inversion estimates 
Figure S-7: The map of the hybrid inventory selected in the study, among 14 new cases shown in Table S-8

Posterior estimates $.5-23$

Table S-10: Description of Six Scenarios of Multi-Platform Inversions in the Study Table S-11: Statistical variables ( $\mathrm{R}^{2}$ and the mean biases) between the observed $\mathrm{CH}_{4}$ mixing ratios (in the 3-hour interval) from the multiplatform and the corresponding simulations using the prior and the posterior estimates, combining different inversion cases in the study

Table S-12: Statewide $\mathrm{CH}_{4}$ emission estimates for 2014-2016 from inversions regarding to the multiplatform, and the associated prior information

Figure S-8: The maps of differences at the spatial distribution of methane emission between the prior and posterior estimates during 2014-2016. The spatial resolution is 0.1 degree, unit: $\mu \mathrm{g} \mathrm{m}^{-2} \mathrm{~s}^{-1}$

Figure S-9: The statewide maps (log scale) of the Fisher information matrix criterion (the diagonal values) during 2014-2016. The spatial resolution is 0.1 degree

Figure S-10: Sub-regional $\mathrm{CH}_{4}$ emission estimates from multiple inversion cases in the study, compared with two gridded bottom-up inventories used in the study. The shaded region in light-green represents previous top-down studies. Cases marked by the light-blue boxes have the best footprint coverage in the corresponding sub-regions (see Table S-6). Inversions in the study include estimates of the exceptional gas leak event at Aliso Canyon. The uncertainty calculated in each inversion case is structured in 1-sigma, and the uncertainties of ensemble results are presented at 95\% confidence (2-sigma)

Sectoral analysis for San Joaquin Valley (SJV)

Table S-13: Sectoral estimates of $\mathrm{CH}_{4}$ emissions in SJV

Temporal variation analysis. S-32

Figure S-11: The posterior ensemble results by year for statewide and four sub-regions. The associated uncertainties are in a $95 \%$ confidence

Figure S-12: The posterior ensemble results by month for statewide and four sub-regions. The associated uncertainties are in a $95 \%$ confidence

Next step S-34

Figure S-13: Map of the on-going CARB additional measurements including (a) GHG monitoring expansion in SJV, and (b) The CARB's Statewide Ceilometer Network and two GC-MS sites

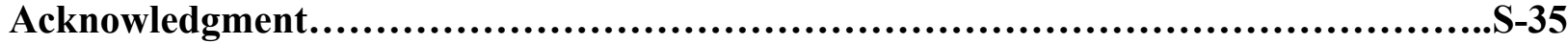

Reference S-36 


\section{Previous top-down studies}

Table S-1: Statewide $\mathrm{CH}_{4}$ emission estimates from the previous top-down studies

\begin{tabular}{|c|c|c|c|c|c|c|}
\hline Study & $\begin{array}{l}\text { Measurement } \\
\text { Year }\end{array}$ & $\begin{array}{l}\text { Measurement } \\
\text { Method }\end{array}$ & $\begin{array}{l}\text { Top-down } \\
\text { method }\end{array}$ & $\begin{array}{l}\text { Top-down } \\
\text { Emission } \\
\text { (Tg/year) } \\
\end{array}$ & $\begin{array}{l}\text { The CARB } \\
\text { inventory } \\
\left(\text { Tg/year) }{ }^{a}\right. \\
\end{array}$ & $\begin{array}{l}\text { Ratio } \\
\text { (Top-down } \\
\text { vs. CARB) }\end{array}$ \\
\hline Zhao et al, 1 & 2007 & Tower & $\begin{array}{l}\text { Inverse } \\
\text { modeling }\end{array}$ & $1.79 \pm 0.28$ & & - \\
\hline Jeong et al, 2 & $\begin{array}{l}\text { September } \\
\text { 2010-June } 2011\end{array}$ & Tower & $\begin{array}{l}\text { Inverse } \\
\text { modeling } \\
(\mathrm{CALGEM})\end{array}$ & $2.3 \pm 0.31$ & 1.58 & $1.3-1.7$ \\
\hline Jeong et al, 2 & $\begin{array}{l}\text { September } \\
\text { 2010-June } 2011\end{array}$ & Tower & $\begin{array}{l}\text { Inverse } \\
\text { modeling } \\
\text { (EDGAR42) }\end{array}$ & $3.1 \pm 0.56$ & 1.58 & $1.6-2.3$ \\
\hline${ }_{3}^{W}$ Wecht et al, & 2010 & $\begin{array}{l}\text { Satellite, } \\
\text { Airplane } \\
\text { sampling }\end{array}$ & $\begin{array}{l}\text { Inverse } \\
\text { modeling }\end{array}$ & $2.86 \pm 0.21$ & 1.58 & $1.7-1.9$ \\
\hline Jeong et al., & $\begin{array}{l}\text { June 2013-May } \\
2014\end{array}$ & Tower & $\begin{array}{l}\text { Inverse } \\
\text { modeling }\end{array}$ & $2.42 \pm 0.49$ & 1.59 & $1.2-1.8$ \\
\hline
\end{tabular}

a. CARB inventory only reports $\mathrm{CH}_{4}$ emissions from the anthropogenic sectors. 
Table S-2: Regional $\mathrm{CH}_{4}$ emission estimates from the previous top-down studies

\begin{tabular}{|c|c|c|c|c|}
\hline Study & $\begin{array}{l}\text { Measurement } \\
\text { year }\end{array}$ & $\begin{array}{l}\text { Measure } \\
\text { ment } \\
\text { Method } \\
\end{array}$ & $\begin{array}{l}\text { Top-down } \\
\text { method }\end{array}$ & $\begin{array}{l}\text { Emission } \\
\text { (Gg/year) }\end{array}$ \\
\hline \multicolumn{5}{|l|}{ SJV a } \\
\hline Jeong et al. (2016) ${ }^{4}$ & 2013-2014 & Tower & \begin{tabular}{|l} 
Inverse \\
modeling
\end{tabular} & $859-1486$ \\
\hline Cui et al. $(2017)^{5}$ & 2010 & $\begin{array}{l}\text { Airplane } \\
\text { sampling }\end{array}$ & \begin{tabular}{|l|} 
Inverse \\
modeling
\end{tabular} & $1183 \pm 245$ \\
\hline \multicolumn{5}{|l|}{ SoCAB b } \\
\hline Wunch et al. (2009) $)^{6}$ & 2008 & FTS & Ratio & $600 \pm 100$ \\
\hline Wennberg et al. $(2012)^{7}$ & $\begin{array}{l}2007-2008 \\
2010\end{array}$ & $\begin{array}{l}\text { Airplane } \\
\text { sampling }\end{array}$ & Ratio & $440 \pm 150$ \\
\hline Peischl et al. $(2013)^{8}$ & 2010 & $\begin{array}{l}\text { Airplane } \\
\text { sampling }\end{array}$ & $\begin{array}{l}\text { Mass } \\
\text { balance }\end{array}$ & $411 \pm 37$ \\
\hline Wong et al. $(2015)^{9}$ & $2011-2013$ & FTS & Ratio & $390 \pm 60$ \\
\hline Wong et al. $(2015)^{9}$ & $2011-2013$ & Tower & Ratio & $370 \pm 50$ \\
\hline Wong et al. $(2015)^{9}$ & $2011-2013$ & Canister & Ratio & $380 \pm 50$ \\
\hline Cui et al. $(2015)^{10}$ & 2010 & $\begin{array}{l}\text { Airplane } \\
\text { sampling }\end{array}$ & $\begin{array}{l}\text { Inverse } \\
\text { modeling }\end{array}$ & $399 \pm 86$ \\
\hline Wunch et al. $(2016)^{11}$ & $2007-2015$ & FTS & Ratio & $413 \pm 86$ \\
\hline Jeong et al. $(2016)^{4}$ & 2013-2014 & Tower & \begin{tabular}{|l} 
Inverse \\
modeling
\end{tabular} & $301-490$ \\
\hline Hedelius et al. $(2018)^{12}$ & $2013-2016$ & TCCON & \begin{tabular}{|l|} 
Inverse \\
modeling
\end{tabular} & $360 \pm 90$ \\
\hline \multicolumn{5}{|l|}{ SV } \\
\hline Jeong et al. $(2016)^{4}$ & $2013-2014$ & Tower & \begin{tabular}{|l|} 
Inverse \\
modeling
\end{tabular} & $164-360$ \\
\hline \multicolumn{5}{|l|}{ SFBA } \\
\hline Fairley et al. $(2015)^{13}$ & 2012 & $\begin{array}{l}\mathrm{CO} \text { AQ } \\
\text { Stations }\end{array}$ & Ratio & $240 \pm 60$ \\
\hline Jeong et al. $(2016)^{4}$ & 2013-2014 & Tower & \begin{tabular}{|l|} 
Inverse \\
modeling
\end{tabular} & $250 \pm 90$ \\
\hline Jeong et al. $(2017)^{14}$ & 2013 & $\begin{array}{l}\text { Tower }+ \\
\text { VOC }\end{array}$ & \begin{tabular}{|l|} 
Inverse \\
modeling
\end{tabular} & $227 \pm 61$ \\
\hline
\end{tabular}

a. Other paper (Johnson et al., $2016^{15}$ focused on the domain including the Northern SJV and the SFBA)

b. Other two papers (Hsu et al., $2010^{16}$ and Kuwayama et al. $2019^{17}$ only focused on LA. County) 


\section{Information of Sites}

Table S-3: Information for Sites Used in the Study during 2014-2016

\begin{tabular}{|l|l|l|l|l|l|}
\hline Sites & $\begin{array}{l}\text { Latitude } \\
\left({ }^{\circ}\right)\end{array}$ & $\begin{array}{l}\text { Longitude } \\
\left({ }^{\circ} \mathrm{E}\right)\end{array}$ & $\begin{array}{l}\text { Altitude } \\
(\mathrm{m} \text { agl })\end{array}$ & $\begin{array}{l}\text { Number } \\
\text { of measurements }{ }^{a}\end{array}$ & Data Period \\
\hline TSB & 40.2621 & -122.0927 & 10 & 25998 & $1 / 2014$ to $12 / 2016$ \\
\hline STB & 39.2056 & -121.8205 & 10 & 24045 & $1 / 2014$ to $12 / 2016$ \\
\hline WGC $^{*}$ & 38.2650 & -121.4911 & 91 & 25297 & $1 / 2014$ to $12 / 2016$ \\
\hline MAD & 36.8672 & -120.0101 & 10 & 19463 & $1 / 2014$ to $12 / 2016$ \\
\hline TRA & 36.6342 & -120.3823 & 10 & 20570 & $1 / 2014$ to $12 / 2016$ \\
\hline ARV & 35.2391 & -118.7887 & 10 & 25278 & $1 / 2014$ to $12 / 2016$ \\
\hline MWO & 34.2211 & -118.0573 & 4 & 12112 & $1 / 2014$ to $12 / 2016$ \\
\hline SBC & 34.0855 & -117.3130 & 58 & 21949 & $1 / 2014$ to $12 / 2016$ \\
\hline CNP & 34.1949 & -118.6045 & 10 & 7328 & $1 / 2016$ to $12 / 2016$ \\
\hline CIT & 34.6094 & -117.2872 & 27 & 2019 & $1 / 2016$ to $12 / 2016$ \\
\hline USC & 34.0214 & -118.2888 & 50 & 15521 & $1 / 2015$ to $12 / 2016$ \\
\hline COM & 33.8738 & -118.2768 & 45 & 16417 & $1 / 2015$ to $12 / 2016$ \\
\hline ONT & 34.0640 & -117.5836 & 41 & 9737 & $1 / 2015$ to $12 / 2016$ \\
\hline FUL & 33.8804 & -117.8841 & 40 & 16182 & $1 / 2015$ to $12 / 2016$ \\
\hline SCI & 32.9154 & -118.4880 & 27 & 17040 & $1 / 2015$ to $12 / 2016$ \\
\hline
\end{tabular}

* WGC is operated through collaboration between LBNL and NOAA.

a. Total number of $\mathrm{CH}_{4}$ measurements sampled at individual sites. Only data obtained during 1217 local time are used in the inversions. SCI is considered as the background site for the MCP network. 


\section{CARB Statewide GHG Monitoring Network}

CARB's Statewide GHG Network uses three different models of Picarro cavity ring-down spectrometer (CRDS) instruments (Models 1301, 2201-I and 2301). The Picarro 1301 is an older model that has been operated successfully at 5 of the long-term sites operated by CARB. The 2301 and 2201-I models are newer. The 2301 model replaced the 1301 model as Picarro's offering for a $\mathrm{CO}_{2}, \mathrm{CH}_{4}$ and $\mathrm{H}_{2} \mathrm{O}$ analyzer. The 2201-I model, used at Mt. Wilson only, provides additional capabilities, providing measurements of both ${ }^{12} \mathrm{C}$ and ${ }^{13} \mathrm{C}$ isotopes in $\mathrm{CH}_{4}$ and $\mathrm{CO}_{2}$, allowing for source apportionment between biogenic and fossil fuel sources of $\mathrm{CH}_{4}$ and $\mathrm{CO}_{2}$.

While the instruments of the CARB GHG network have different model numbers, we can state that all instruments are capable of having very similar performances in terms of measurement precision and drift as listed in the Table below. Clearly the newer 2301 instrument type has some improvements over the older 1301 units, but they are incremental and both instrument generations are capable of delivering highly accurate data when calibrated and maintained appropriately (see Table below). The sites with Picarro 1301s were calibrated approximately every 6 months with NOAA standard gases traceable to the WMO scale, and a single calibration gas standard was run through the instrument every 24 hours to check the instrument performance in between calibrations. For the sites with the Picarro 1301s, this 24 hours drift check data was used to check if the values exceeded the factory specifications of precision and drift. If exceeded, data were flagged and excluded. A typical instrument drift for a 1301 deployed at Arvin showed a drift of 2 ppb over a typical 3-6 month period for example. Other sites (MWO, SBC and WGC) used an automated calibration scheme with multiple calibration standard gases multiple times a day. While this allows for better tracing of instrument performance and stability, the Picarro CRDS $\mathrm{CH}_{4} / \mathrm{CO}_{2} / \mathrm{H}_{2} \mathrm{O}$ have proven to be stable and accurate enough to operate with calibration on weekly or even monthly scales without much degradation of accuracy. The afternoon enhancements (in a 3-hour interval) of $\mathrm{CH} 4$ at sites throughout the network ranged from $200-500 \mathrm{ppb}$ up to $\sim 1500 \mathrm{ppb}$ during this study, depending on the site and season. The observed enhancements were far above the instrument specifications for precision and drift, which are in the low ppb range (Table S-4).

More details are available in the Quality Assurance Project Plan (QAPP) at https://ww2.arb.ca.gov/our-work/programs/ghg-network/about.

Table S-4: Information for three models of Picarro Cavity Ring down Spectrometer (CRDS) instruments

\begin{tabular}{|l|l|l|l|l|}
\hline CRDS Instrument & Precision & $\begin{array}{l}\text { Precision } \\
(1 \mathrm{~s}-600 \mathrm{secs})\end{array}$ & Drift (Day) & Drift (Month) \\
\hline Picarro 1301 & $<1.5 \mathrm{ppb}(1 \mathrm{~s}-30 \mathrm{secs})$ & $\mathrm{n} / \mathrm{a}$ & $1.5 \mathrm{ppb}(30 \mathrm{hrs})$ & $\mathrm{n} / \mathrm{a}$ \\
\hline Picarro 2201-I & $\begin{array}{l}6 \mathrm{ppb} @ 2000 \mathrm{ppb} \\
\text { reading (1s - 30 secs) }\end{array}$ & $\mathrm{n} / \mathrm{a}$ & $\begin{array}{l}<2.3 \mathrm{ppb}(24 \mathrm{hrs}) @ \\
2000 \mathrm{ppb} \text { reading }\end{array}$ & $\mathrm{n} / \mathrm{a}$ \\
\hline Picarro 2301 & $<0.5 \mathrm{ppb}(1 \mathrm{~s}-5 \mathrm{secs})$ & $0.22 \mathrm{ppb}$ & $<1 \mathrm{ppb}(24 \mathrm{hrs})$ & $3 \mathrm{ppb}$ \\
\hline
\end{tabular}

At WGC, SBC and MWO, multiple daily calibrations were conducted with two secondary gas standards provided by Scott Marrin, Inc., which were cross referenced to the NOAA calibrated standard reference gases ${ }^{2,18}$. For the other 5 sites (TSB, STB, MAD, TRA, and ARV) in the GHG 
network, daily drift checks with one gas standards provided by Scott Marrin were performed to track instrument performance against factory specifications. These instruments were calibrated with NOAA calibrated standard reference gases every 6 months and the secondary standards used for drift checks at each of these sites were cross referenced to NOAA calibrated standards. Calibration and where available drift check results were used to compute mixing ratios for each sample that were then averaged to hourly values and used for the study.

Based on this study, we consider that the current configuration of CARB Statewide GHG Monitoring Network (8 sites) could constrain $\mathrm{CH}_{4}$ emissions at the air-basin scale, such as the San Joaquin Valley (SJV), the South Coast Air Basin (SoCAB), San Francisco Bay Area (SFBA), and Sacramento Valley (SV), but could have large uncertainties on sub-basin scales. We calculated the averaging kernel matrix $(\boldsymbol{A})$ to describe the sensitivity of the retrieved emissions to true emissions:

$$
A=I_{n}-\left(W R^{-1} W^{T}\right)^{-1} B^{-1}(1)
$$

, which derives the values of degree of freedoms (DOFs) from our inversions, where $\boldsymbol{W}$ is the Jacobian matrix in the log space ${ }^{19}$. The aggregated values of DOFs in SJV, SoCAB, SFBA, and SV to be 2-5, 3-10, 1-2, and 2-7 from our "2014_Inv", "2015_Inv" and 2016_Inv" initialized by three different prior inventories, indicating that we have confidence to constrain 2-5, 3-10, 1-2, and 2-7 independent pieces of information in these regions, respectively. Two other platforms (MCP and AJAX) used in the study could increase the $\mathrm{DOF}_{\mathrm{S}}$ in the SoCAB region, and the $\mathrm{SJV} / \mathrm{SV} / \mathrm{SFBA}$ regions.

According to the total area of each domain and the associated DOFs, with a very simple assumption, we calculated the best spatial resolution in four regions that could be constrained using the current CARB GHG Monitoring Network (Table S-5).

Table S-5: Best constrained spatial resolution for four sub-regions in California

\begin{tabular}{|l|l|l|l|}
\hline & Areas $\left(\mathbf{k m}^{2}\right)$ & DOFs & $\begin{array}{c}\text { Best constrained } \\
\text { spatial resolution }\end{array}$ \\
\hline SJV & 61,315 & $2-5$ & $111 \times 111 \mathrm{~km}$ \\
\hline SoCAB & 18,038 & $3-10$ & $42 \times 42 \mathrm{~km}$ \\
\hline SFBA & 14,454 & $1-2$ & $85 \times 85 \mathrm{~km}$ \\
\hline SV & 39,179 & $2-7$ & $75 \times 75 \mathrm{~km}$ \\
\hline
\end{tabular}




\section{$\underline{\text { WRF configuration }}$}

The physics schemes in WRF include the RRTM long-wave radiation scheme ${ }^{20}$, the Dudhia shortwave radiation $s c h e m e^{21}$, the Yonsei University planetary boundary layer scheme ${ }^{22}$, the Pleim-Xiu land-surface model ${ }^{23-24}$, the WRF single moment 6-class microphysics scheme ${ }^{25}$, and the KainFritsch cumulus scheme ${ }^{26}$. We used North American Regional Reanalysis data to provide initial and boundary conditions for WRF.

\section{FLEXPART-WRF}

Figure S-1 shows an averaged footprint map integrating back-trajectories. During the inversion calculation process, we used individual footprints for each receptor. Table S-6 presents a variety of cases which combined monitoring data from the different available platforms, to identify the dataset in each region which provided the highest footprint coverage.
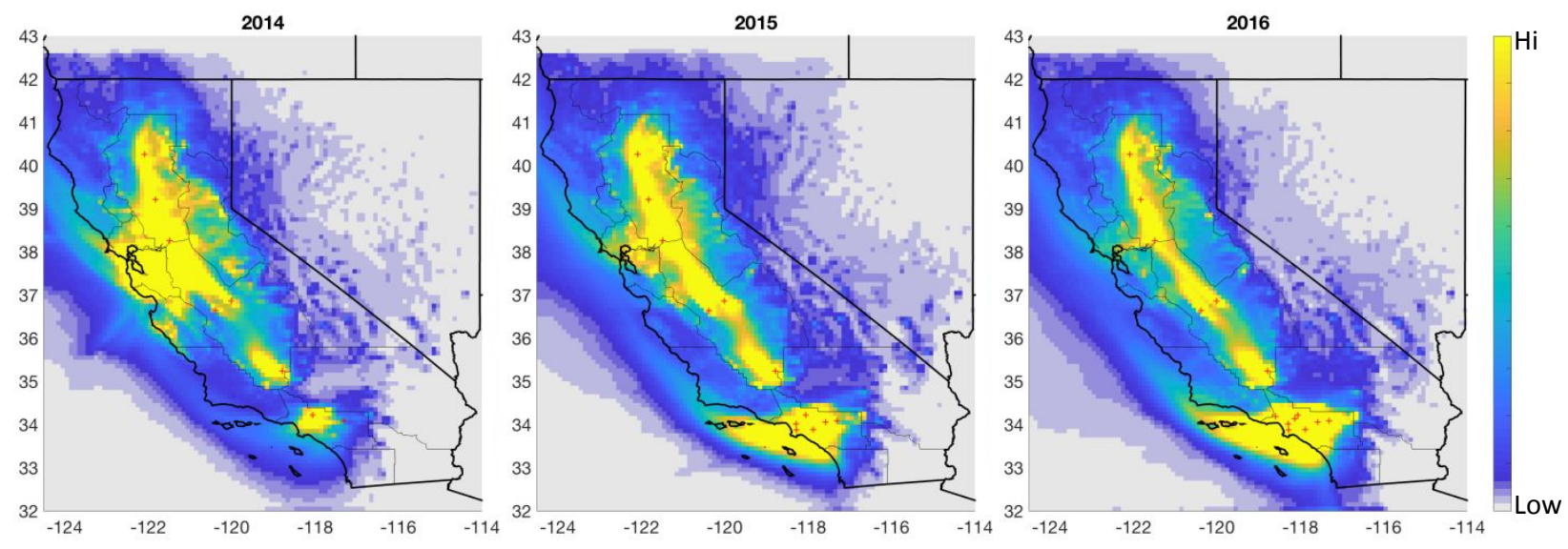

Figure S-1: The averaged sensitivity maps (i.e. "footprint") of the receptors to the surface fluxes for 2014-2016. 
Table S-6: Footprint values for each composite dataset in each region (unit: $\mathrm{s} \mathrm{m}^{2} / \mu \mathrm{g}$ )

\begin{tabular}{|c|c|c|c|c|}
\hline Cases & SoCAB & SJV & SV & SFBA \\
\hline 2014 CARB towers & 9288 & 32623 & 29693 & 7413 \\
\hline 2015 CARB towers & 8937 & 48029 & 40825 & 10707 \\
\hline 2016 CARB towers & 9983 & 40770 & 32724 & 7797 \\
\hline $\begin{array}{lll}2014 \text { CARB towers }+ \\
\text { AJAX flights }\end{array}$ & 9292 & 50095 & 38657 & 24660 \\
\hline 2015 CARB + MCP towers & 27723 & 48571 & 40841 & 10730 \\
\hline 2016 CARB + MCP towers & 42343 & 41968 & 32768 & 7871 \\
\hline Best Case & $\begin{array}{l}2016 \text { CARB }+ \\
\text { MCP towers }\end{array}$ & $\begin{array}{l}2014 \quad \text { CARB } \\
\text { towers+ } \\
\text { Flights }\end{array}$ & $\begin{array}{l}2015 \quad \text { CARB } \\
\text { towers } \\
2015 \text { CARB + } \\
\text { MCP towers }{ }^{\text {a }}\end{array}$ & $\begin{array}{ll}2014 & \text { CARB } \\
\text { towers }+ & \text { AJAX } \\
\text { Flights } & \end{array}$ \\
\hline
\end{tabular}

a. cases of "2015 CARB towers" and "2015 CARB towers + MCP towers" have very similar values, and we used both of them in the study

We simulated the back-trajectories during 3,5 and 7 days for the CARB's Statewide GHG Monitoring Network and noticed that the 5-day and 7-day back-trajectory simulations derived similar footprints to the 3-day simulation in the domain of interest. Therefore, we used the 3-day back-trajectory simulation to derive the footprints for the CARB's Statewide GHG Monitoring Network to obtain computational efficiency. Similarly, we conducted some sensitivity tests and decided to use the 1-day back-trajectory simulations to calculate the footprints for MCP. The backward time periods are also consistent with Cui et al. ${ }^{5,10}$. For the aircraft measurements, we consider each 30-second averaged data point as a receptor, and we simulated 1-day backtrajectories for each receptor, similar to Cui et al. ${ }^{5,10}$.

\section{$\underline{\text { Inverse modeling framework }}$}

In the system, we numerically minimize a lognormal Bayesian cost function with solutions in a median of the distribution and with assuming errors to be of multiplicative nature $5,10,19,27$. This approach is also able to avoid the negative unphysical solution:

$$
\mathrm{J}(\mathrm{x})=\frac{1}{2}\left(\ln \left(\mathrm{y}_{0}\right)-\ln (\mathrm{Hx})\right)^{\mathrm{T}} \mathrm{R}^{-1}\left(\ln \left(\mathrm{y}_{0}\right)-\ln (\mathrm{Hx})\right)+\frac{1}{2} \alpha\left(\ln (\mathrm{x})-\ln \left(\mathrm{x}_{0}\right)\right)^{\mathrm{T}} \mathrm{B}^{-1}(\ln (\mathrm{x})-
$$

$\left.\ln \left(\mathrm{x}_{0}\right)\right)(2)$

where $\boldsymbol{y}_{\boldsymbol{0}}$ (dimension: $\mathrm{m} \times 1$ ) is the measured time series of $\mathrm{CH}_{4}$ mixing ratio enhancement above defined background; $\boldsymbol{x}_{\mathbf{0}}$ (dimension: $\mathrm{n} \times 1$ ) is the prior emission inventory; $\boldsymbol{H}$ (dimension: $\mathrm{m} \times \mathrm{n}$ ) is the source-receptor relationship matrix calculated by FLEXPART-WRF. We adjust and optimize $\boldsymbol{x}$ (posterior emission, dimension: $\mathrm{n} \times 1$ ) to minimize the cost function $\mathrm{J}(\mathrm{x})$. We focus on the domain of California at a 0.1 degree spatial resolution and the number of $\mathrm{n}$ is $4178 . \boldsymbol{R}$ (dimension: $\mathrm{m} \times \mathrm{m}$ ) and $\boldsymbol{B}$ (dimension: $\mathrm{n} \times \mathrm{n}$ ) are the error covariance matrices of the modelobservation mismatch and the prior emissions, respectively. $\boldsymbol{R}$ and $\boldsymbol{B}$ are diagonal matrices in the study; $\boldsymbol{\alpha}$ is a regularization parameter used to tune the balance between the contributions of modelobservation errors and the constraints of the prior emission estimates ${ }^{28}$. 
$\boldsymbol{R}$ was constructed to be the sum of squares of the measurement precision $\left(\sigma_{p}\right)$, measurement/aggregation uncertainty $\left(\sigma_{m}\right)$, background uncertainty $\left(\sigma_{b}\right)$, and the uncertainty of the transport model $\left(\sigma_{t}\right)$.

$$
R=\sigma_{p}^{2}+\sigma_{m}^{2}+\sigma_{b}^{2}+\sigma_{t}^{2}
$$

$\boldsymbol{B}$ was constructed to be the square of the prior uncertainty $\left(\sigma_{\text {prior }}\right)$.

$$
B=\sigma_{\text {prior }}^{2}
$$

\begin{tabular}{|c|c|c|}
\hline & This study & Magnitude (1-sigma) \\
\hline$\sigma_{\mathrm{p}}$ & $\begin{array}{l}\text { Compared to } \mathrm{CH}_{4} \text { enhancement (e.g 3-hour } \\
\text { interval, } 120 \pm 150 \mathrm{ppb} \text { ), it's very small (e.g } \\
1.5 \mathrm{ppb} \text { ), we do not include it in the study. }\end{array}$ & \\
\hline$\overline{\sigma_{\mathrm{m}}}$ & $\begin{array}{l}\text { The standard deviation of the aggregated } \\
\text { measurements in 3-hour intervals. }\end{array}$ & $\begin{array}{l}\text { 2014: } 23 \pm 27 \mathrm{ppb} \\
\text { 2015: } 22 \pm 25 \mathrm{ppb} \\
\text { 2016: } 22 \pm 27 \mathrm{ppb} \\
\end{array}$ \\
\hline$\sigma_{\mathrm{b}}$ & $\begin{array}{l}40 \text { ppb for all MCP sites was used, which is } \\
\text { consistent with the recently published paper } \\
\text { of Yadav et al., }(2019) \text {, and } 20 \text { ppb for the } \\
\text { rest of the sites based on measurements } \\
\text { from a remote site (THD) and the zonal } \\
\text { averaged CH } 4 \text { mixing ratios during 2014- } \\
2016 \text { between 35-43 from NOAA } \\
\text { Greenhouse Gas Marine Boundary Layer } \\
\text { Reference data. }\end{array}$ & $\begin{array}{l}40 \mathrm{ppb} \text { for MCP } \\
20 \mathrm{ppb} \text { for the rest }\end{array}$ \\
\hline$\overline{\sigma_{\mathrm{t}}}$ & $\begin{array}{l}65 \% \text { relative error of the measurement } \\
\text { enhancement. The magnitude of } \sigma_{t} \text { is } \\
\text { determined as an upper bound of the WRF } \\
\text { evaluations at the regional scale for the } \\
\text { study (described in the section of } \\
\text { "Atmospheric transport") as a conservative } \\
\text { analysis. This assumption is also } \\
\text { comparable with the previous relevant } \\
\text { studies Jeong et al. }{ }^{2} \text { and Bagley et al. }{ }^{29} \text { (i.e } \\
30 \%-60 \% \text { ). }\end{array}$ & $\begin{array}{l}\text { 2014: } 82 \pm 99 \mathrm{ppb} \\
\text { 2015: } 88 \pm 113 \mathrm{ppb} \\
\text { 2016: } 75 \pm 82 \mathrm{ppb}\end{array}$ \\
\hline$\sigma_{\text {prior }}$ & $\begin{array}{l}\text { We gave a } 100 \% \text { relative uncertainty to the } \\
\text { prior inputs and used } \alpha \text { to adjust the original } \\
\text { assumption during the inversion process. }\end{array}$ & $\begin{array}{l}\text { CALGEM: } 0.13 \pm 0.48 \mathrm{ug} \mathrm{m}-2 \mathrm{~s}-1 \\
\text { EPAGHGI: } 0.14 \pm 0.30 \mathrm{ug} \mathrm{m}-2 \mathrm{~s}-1 \\
\text { Hybrid: } 0.70 \pm 0.07 \mathrm{ug} \mathrm{m}-2 \mathrm{~s}-1 \\
\\
\text { The range of } \alpha \text { to be } 5-20 .\end{array}$ \\
\hline
\end{tabular}

Table S-7: Information for parameters in the inverse modeling setup

More details of the inverse model, such as the final posterior uncertainty calculation by grid cell and by region, could be found in Cui et al. ${ }^{5}$. We report the uncertainty associated with the ensemble results to be a $95 \%$ confidence ( 2 -sigma rule) so that to be consistent with the estimation from 
Jeong et al. ${ }^{4}$ and Cui et al. ${ }^{27}$ The uncertainty associated each inversion case were derived in the 1sigma rule, following the nature of the variational method.

This mesoscale inverse modeling system has been used to optimize emission fluxes for several studies $^{5,10,27}$ but was only focused on aircraft measurements. In this study, we used two tower networks and one aircraft campaign to achieve the multiplatform inversions. Therefore, besides the same treatment for the aircraft measurements as our previous work, we made the criterion to handle the tower measurements in the study: (1) we used the 3-hour interval (for the computational efficiency), same to previous relevant work ${ }^{2}{ }^{4}$, the aggregation error has been included in $\boldsymbol{R}$; (2) we did not use the outliers (i) of the 3 -hour averaged measurements if the associated $\sigma_{m, i}$ is larger than 3 times the standard deviation of all $\sigma_{m}{ }^{30}$, to exclude the local impacts that could not be handled by current mesoscale model framework and also not be the focus of this study for the statewide and regional emission estimation; (3). We only focused on the measurements of MCP sites associated with wind speed within $2-9 \mathrm{~m} / \mathrm{s}$ to exclude the local impacts, which is consistent with Yadav et al. ${ }^{31}$, while the rest of sites were not applied the rule in the current work due to a lack of co-located wind measurements.

\section{$\underline{\text { PBLH evaluation }}$}

To evaluate WRF simulated PBLHs, we used PBLH retrievals from four different observation platforms, including radiosonde, wind radar profiler, ground-based LiDAR, and aircraft sounding (Figure S-2).

1) Radiosonde: six radiosonde stations in California existed during 2014-2016 (https://ruc.noaa.gov/raobs/). Considering the completeness of the data sets in the time period (1217 local time, 2014-2016), we used the PBLH retrievals from two of the six stations ("OAK" and "NKX") to evaluate the model performance. We used two methods ${ }^{32-33}$ to derive PBLHs from the radiosonde data and only chose the similar values determined by the two methods to evaluate the model performance. Radiosonde stations are only located along the coast, so that the representatives of model evaluation are limited.

2) Radar wind profiler: we also used the available virtual temperature data from a radar wind profiler ("VIS", Figure S4) in the San Joaquin Valley to derive additional PBLH information. We used the Holzworth method ${ }^{34}$ to determine hourly PBLHs at VIS during 2014-2016 and focused on the time period of 12-17 local time. Additional PBLH retrievals from Radar wind profiler stations were used as well ${ }^{35}$, although they are only available for half of 2014.

3) Ground-based LiDAR instrument: we used the long-term PBLH retrievals by a miniMPL and a co-located ceilometer in the CalTech site of the Megacities Carbon Project, during 2014-2016 ${ }^{36}$.

4) Aircraft sounding: we retrieved PBLHs from available aircraft sounding data during 2014-2016 using the Holzworth method ${ }^{34}$. The aircraft data were obtained from AIRCAR which were provided by the National Center for Atmospheric Research (NCAR) Research Data Archive (RDA) (https://rda.ucar.edu/datasets/ds351.0/). Flight trajectories were reconstructed from data points, and only soundings that satisfied the following criteria were considered potentially useful for 
PBLH retrievals: 1) more than 5 data points below the $600 \mathrm{mb}$ or $3 \mathrm{~km}$ level; 2) the lowest point has pressure larger than $900 \mathrm{mb}$, or height lower than $1 \mathrm{~km} ; 3$ ) total horizontal span of profile is less than $4 \mathrm{~km}$, consistent with model grid spacing; 4) total duration of profile is less than 30 minutes, based on typical take-off or landing duration of commercial planes.

PBLH evaluations are shown in Figure S-3, associated with the analysis of mean biases $(\mathrm{m})$ and the ratio (\%) of the mean biases to the measurement-retrieved PBLHs on average. The statistical analysis provided the reference to assign the transport model uncertainty in the study.

More measurement-based PBLHs retrievals will be available to evaluate models associating with the program of CARB ceilometer network in near future (Figure S-15).

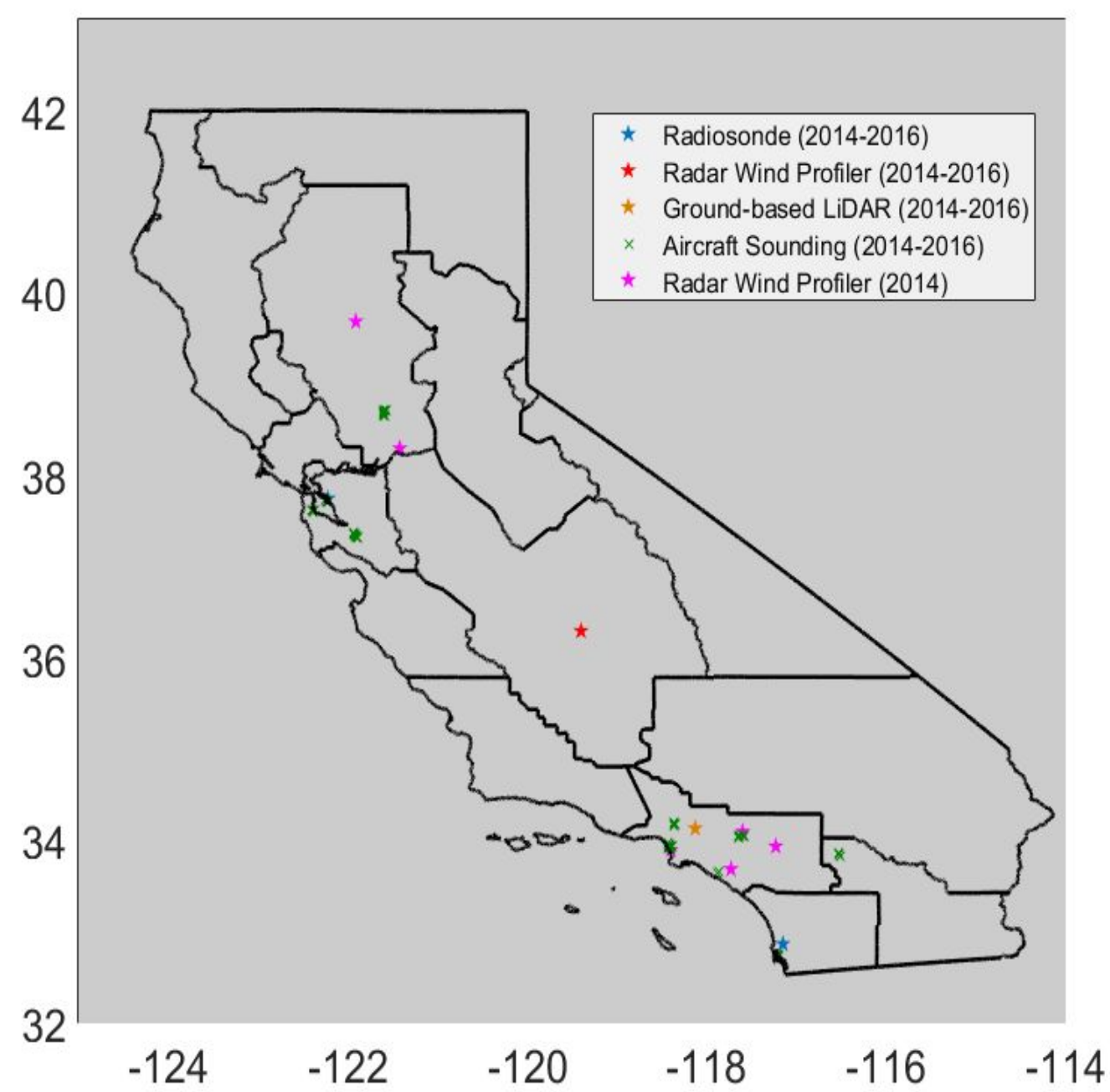

Figure S-2. A map of PBLH retrieval locations, which are used to evaluate WRF PBLH performances for 2014-2016. 
2014
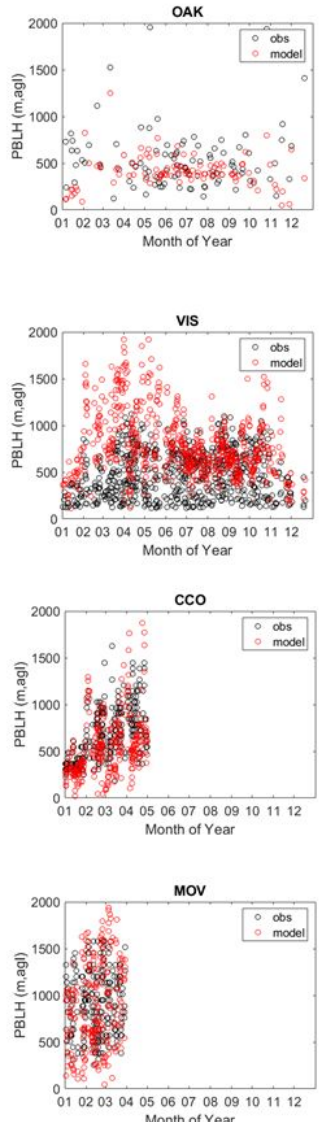

Month of Year

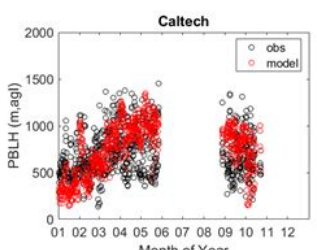

Month of Year

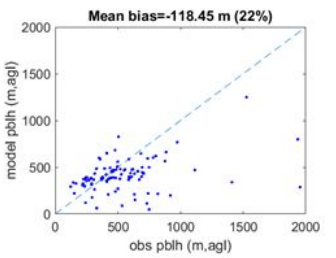

Radiosonde
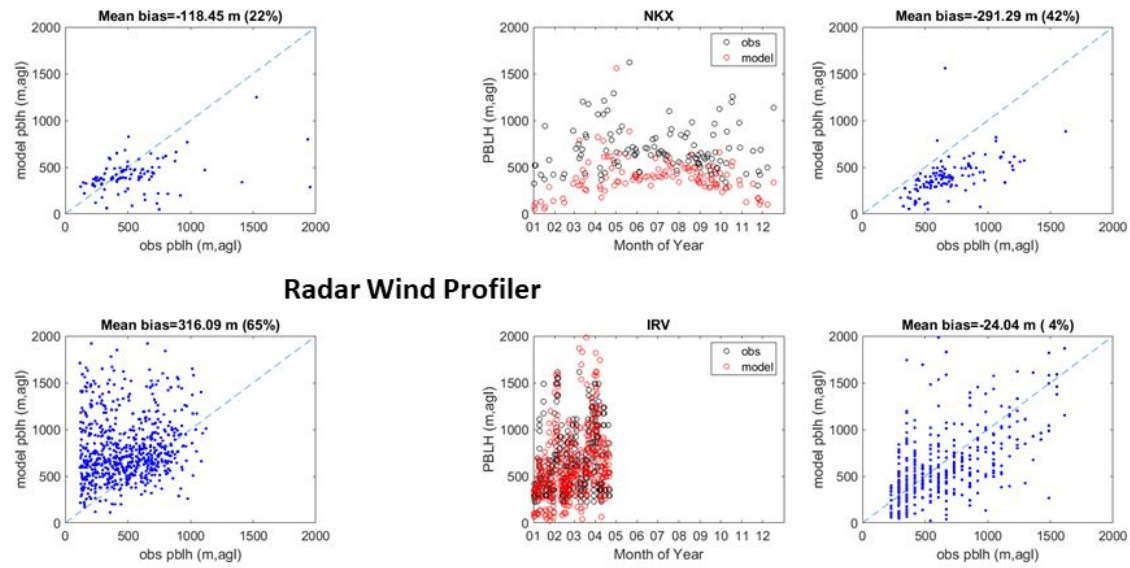

Radar Wind Profiler
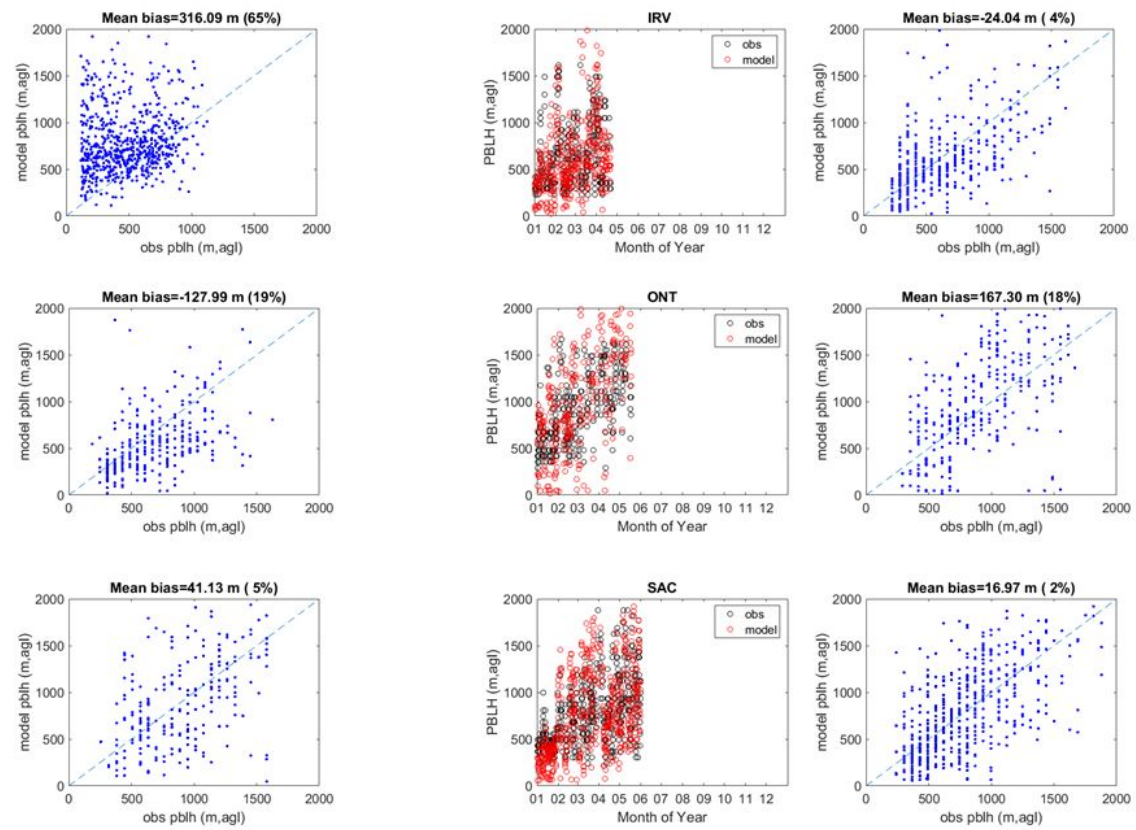

Ground-based LiDAR
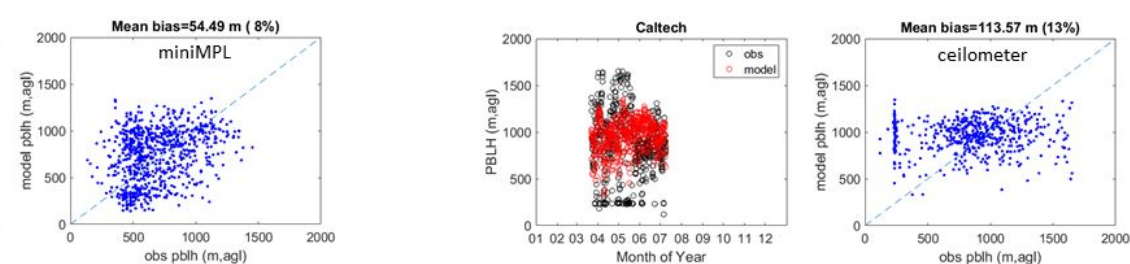

Aircraft Sounding
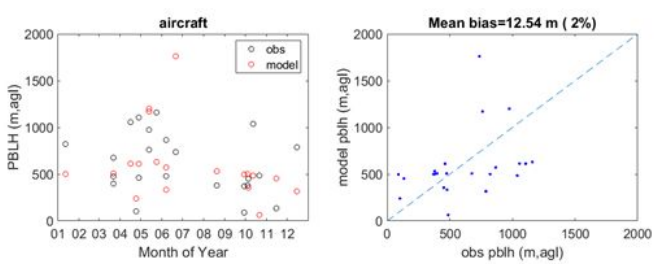

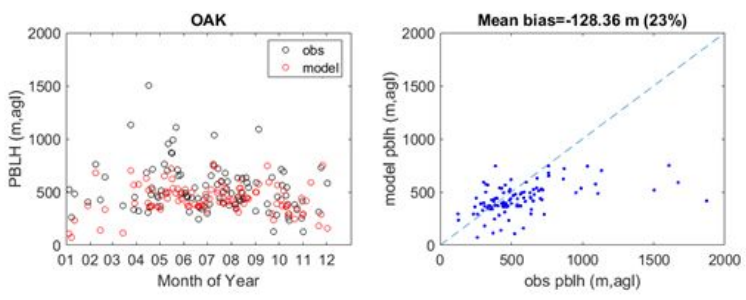

\section{Radiosonde}
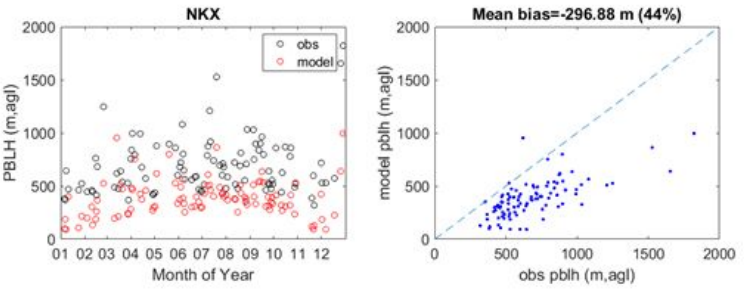

\section{Radar Wind Profiler}
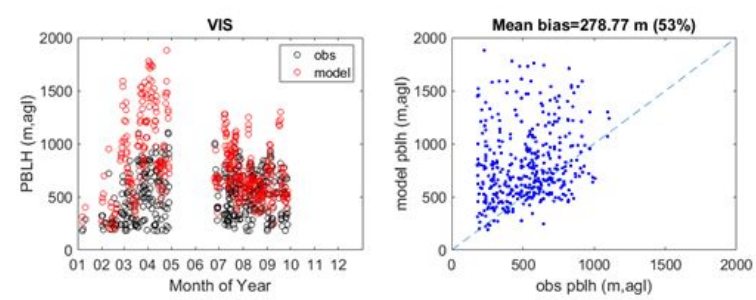

\section{Ground-based LiDAR}
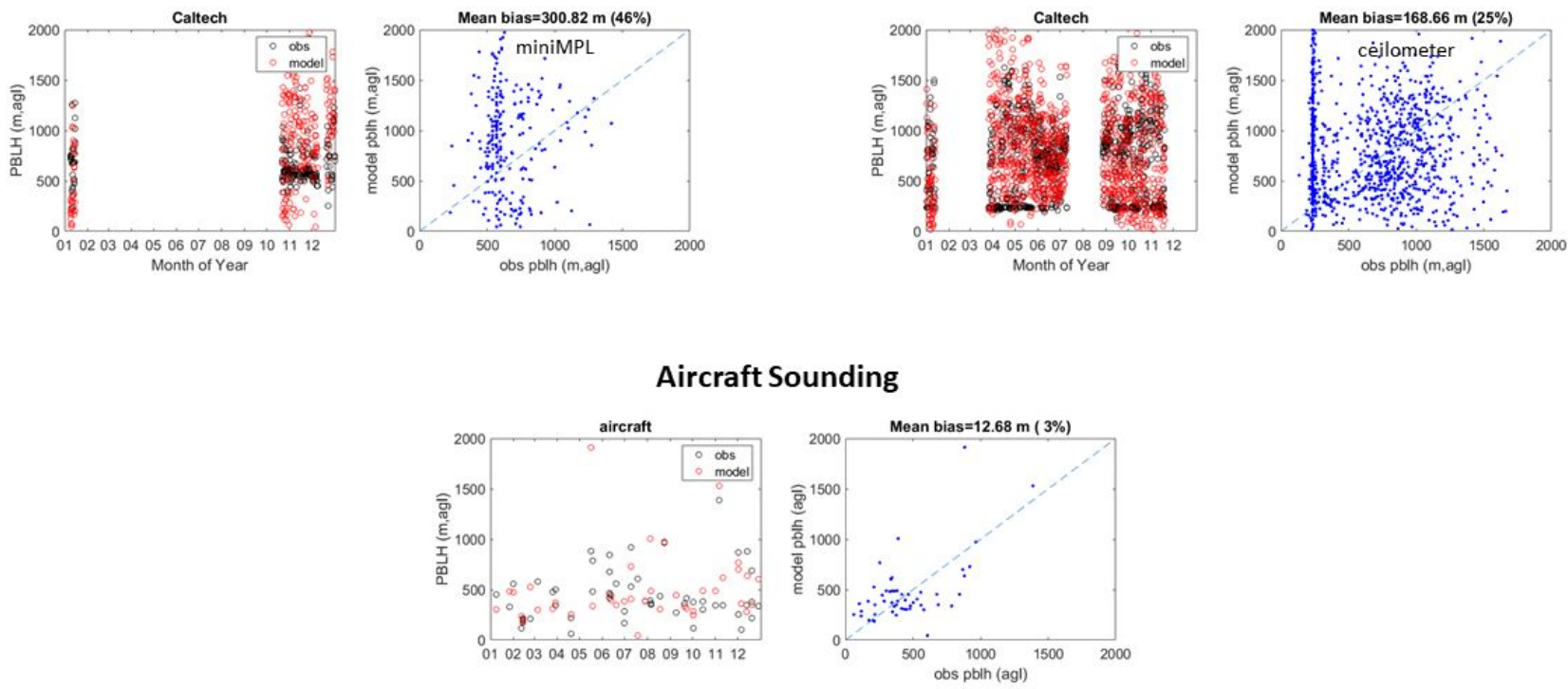

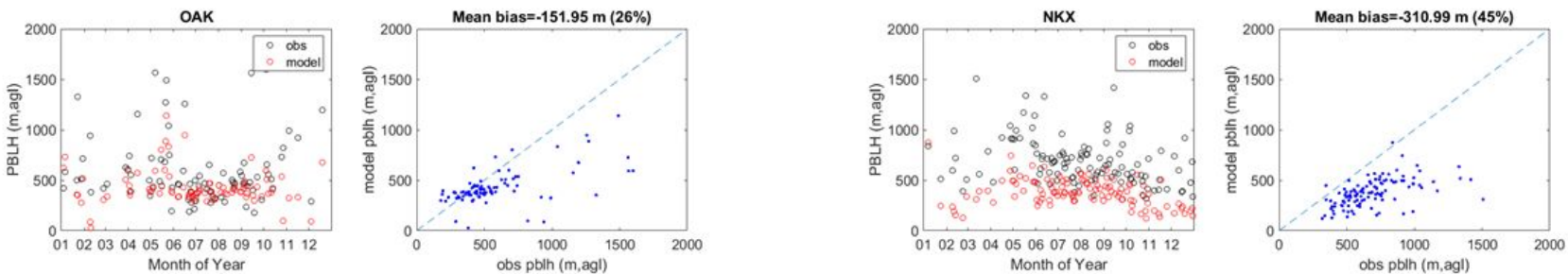

\section{Radar Wind Profiler}
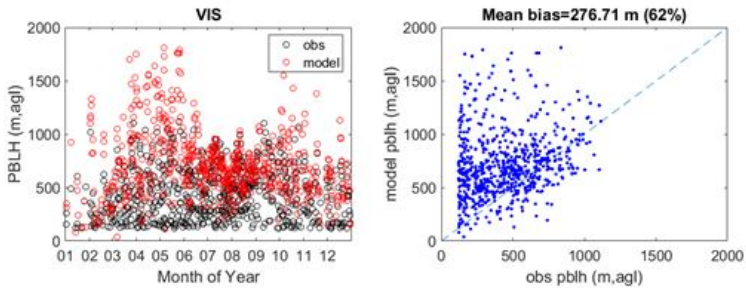

Ground-based LiDAR
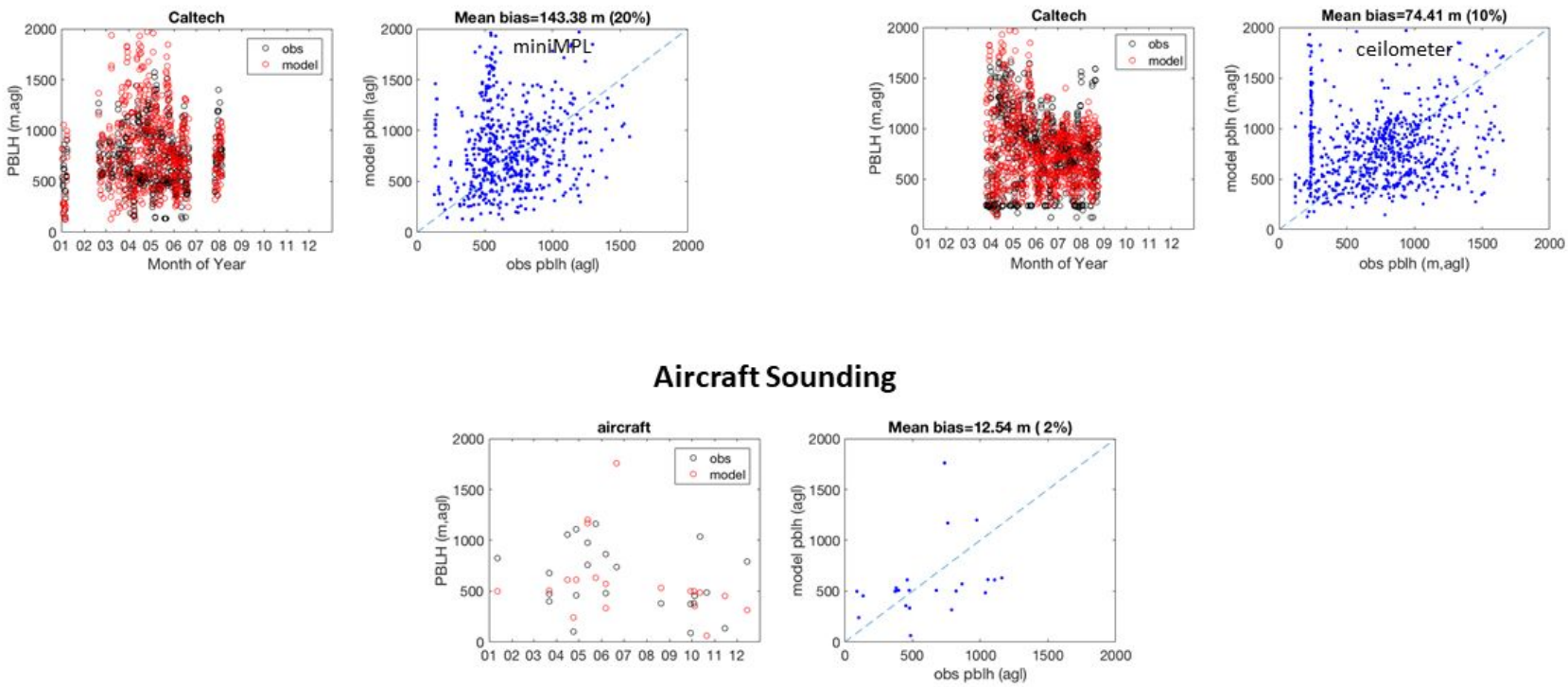

Figure S-3. Planetary Boulder Layer Heights (PBLH) simulated by WRF in the work are compared with the measurement-determined values from different observation platforms, during the year of 2014-2016. The mean biases (unit: $\mathrm{m}$ above ground level) are shown as well as the values in the brackets representing the absolute values of the ratio (\%) of the mean biases to the measurement-determined PBLHs on average.

\section{Prior inventory}


Two spatially resolved prior inventories are shown in the annual emission level (Figure S-4), and the comparisons between the simulated $\mathrm{CH}_{4}$ mixing ratios using the two prior inventories and the observations are shown in Figure S-5.

We make 16 combinations based on four source categories including dairy, $\mathrm{O} / \mathrm{NG}$, landfills, and others (Table S-8). The 16 hybrid inventories were used to simulate $\mathrm{CH}_{4}$ mixing ratios (Figure S6 ) and the combination that derived the best $\mathrm{R}^{2}$ against observations was chosen to be the third prior input (Figure S-7) in the work.

The statewide $\mathrm{CH}_{4}$ emission estimates in $\mathrm{Tg} / \mathrm{yr}$ by major sectors for three prior inventories are shown in Table S-9.
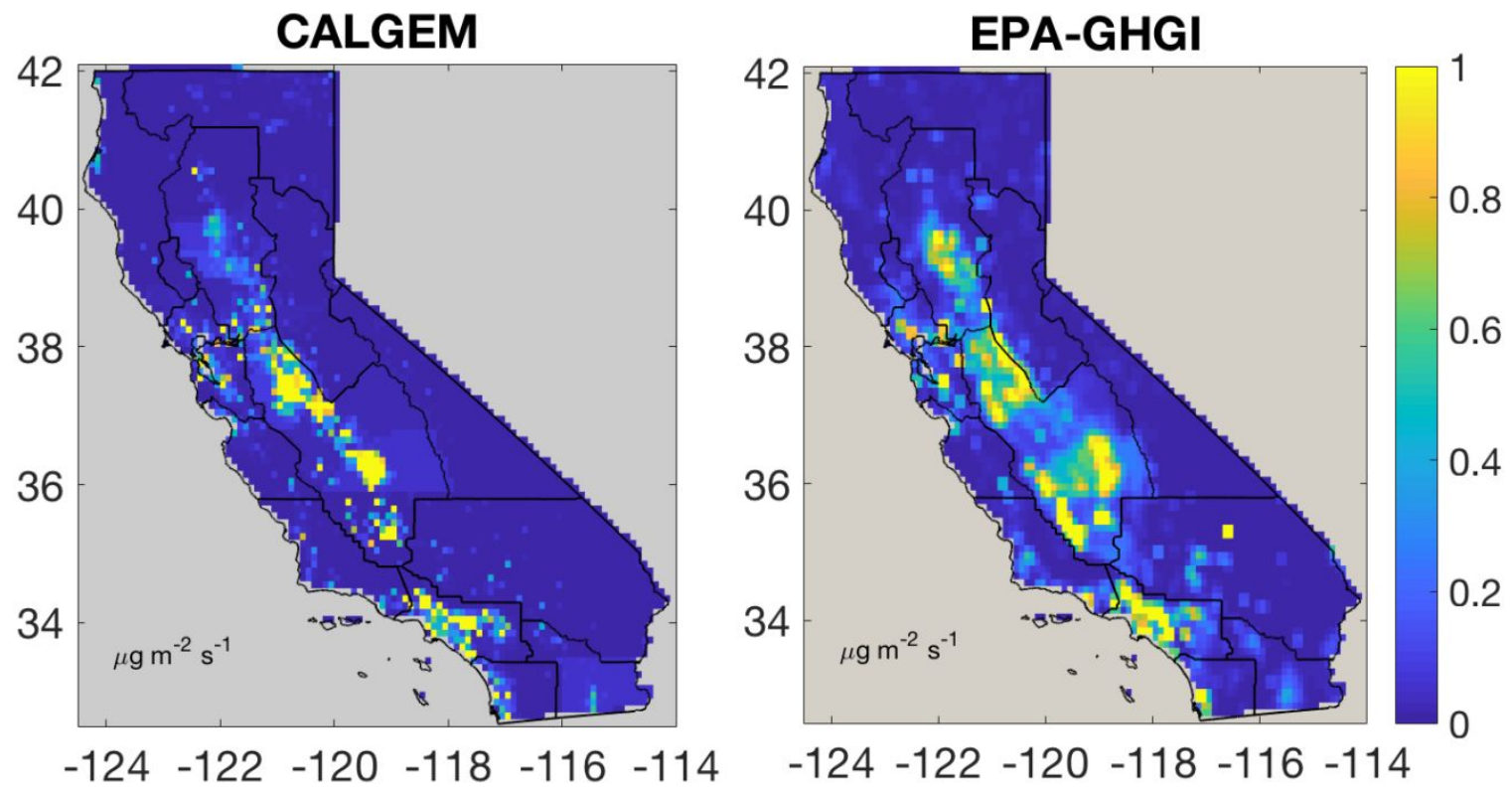

Figure S-4: Two prior inventories (CALGEM version 3 and EPA-GHGI, unit: $\mu \mathrm{g} \mathrm{m}^{-2} \mathrm{~s}^{-1}$ ) used in the inversion estimates. 
CALGEM

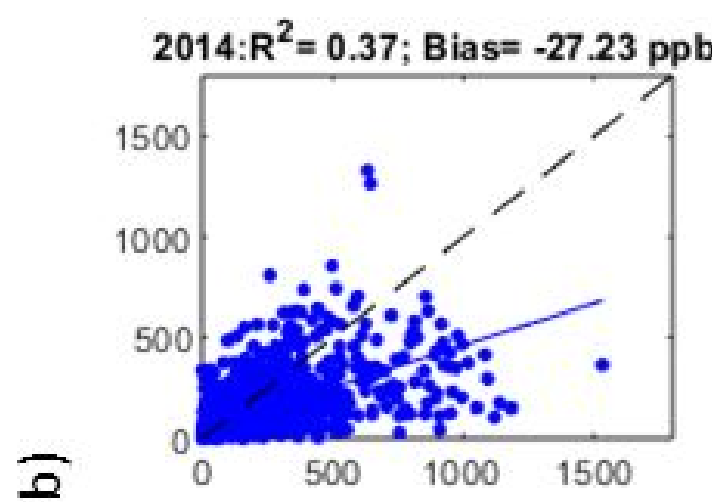

EPAGHGI
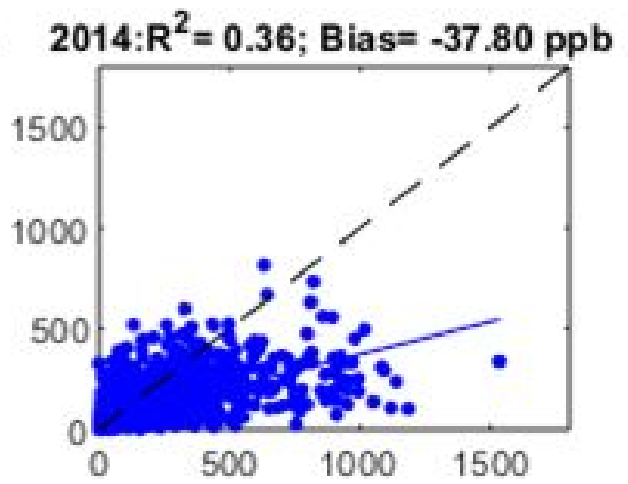

$2015: R^{2}=0.39 ;$ Bias $=-44.83 p p b$

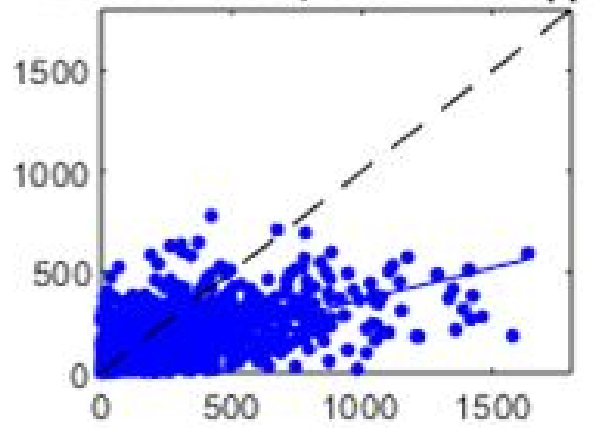

$2016: R^{2}=0.31 ;$ Bias $=-24.24 \mathrm{ppb}$

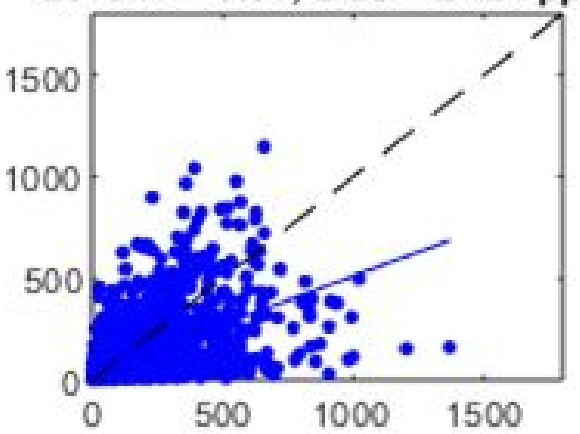

$2016: R^{2}=0.33 ;$ Bias $=-32.73 \mathrm{ppb}$

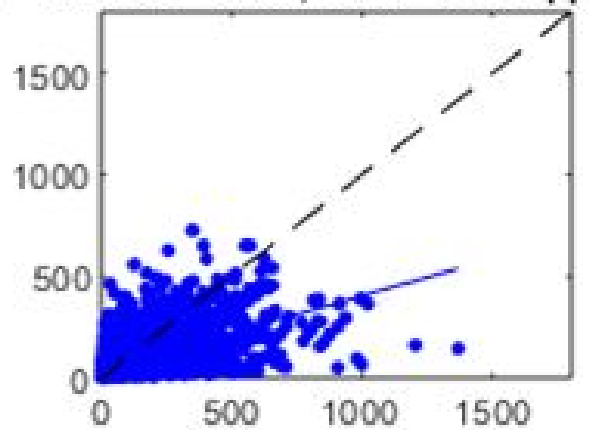

Observed $\Delta \mathrm{CH}_{4}(\mathrm{ppb})$

Figure S-5: Comparisons of measured and simulated $\mathrm{CH}_{4}$ mixing ratios using the two prior inventories, which are CALGEM v3 and EPA-GHGI shown in Figure S2. The coefficient of determination $\left(\mathrm{R}^{2}\right)$ and mean biases (unit: $\mathrm{ppb}$ ) are shown. 
Table S-8: Information of 16 inventories ${ }^{\text {a }}$

\begin{tabular}{|lllll}
\hline & Landfills & Dairy & Oil \& Gas & Others \\
\hline 1 & CALGEM & CALGEM & CALGEM & CALGEM \\
3 & EPA-GHGI & EPA-GHGI & EPA-GHGI & EPA-GHGI \\
4 & CALGEM & CALGEM & EPA-GHGI & CALGEM \\
5 & CALGEM & EPA-GHGI & CALGEM & CALGEM \\
6 & EPA-GHGI & CALGEM & CALGEM & CALGEM \\
7 & EPA-GHGI & EPA-GHGI & CALGEM & CALGEM \\
8 & EPA-GHGI & CALGEM & EPA-GHGI & CALGEM \\
9 & CALGEM & EPA-GHGI & EPA-GHGI & CALGEM \\
10 & CALGEM & CALGEM & EPA-GHGI & EPA-GHGI \\
11 & CALGEM & EPA-GHGI & CALGEM & EPA-GHGI \\
12 & EPA-GHGI & CALGEM & CALGEM & EPA-GHGI \\
13 & EPA-GHGI & EPA-GHGI & CALGEM & EPA-GHGI \\
14 & EPA-GHGI & CALGEM & EPA-GHGI & EPA-GHGI \\
\hline 16 & CALGEM & EPA-GHGI & EPA-GHGI & EPA-GHGI \\
\hline 14 & CALGEM & CALGEM & CALGEM & EPA-GHGI \\
& EPA-GHGI & EPA-GHGI & EPA-GHGI & CALGEM \\
\hline & & & &
\end{tabular}

a. \#1-\#2: CALGEM and EPA-GHGI, respectively; \#3-\#16: 14 different hybrid inventories based on CALGEM and EPA-GHGI. \#8: selected as the optimized hybrid prior inventory used in inversion estimates.

Table S-9: Statewide $\mathrm{CH}_{4}$ emission estimates in $\mathrm{Tg} / \mathrm{yr}$ by sector for three prior inventories

\begin{tabular}{|l|l|l|l|}
\hline Sector & CALGEM & EPA-GHGI & Hybrid \\
\hline Dairy and Livestock (DLS) & 0.7398 & 0.8803 & 0.8803 \\
\hline Landfills (LF) & 0.3432 & 0.5036 & 0.3432 \\
\hline Oil and Natural Gas (ONG) & 0.3144 & 0.3247 & 0.3247 \\
\hline Others & 0.3111 & 0.2117 & 0.3111 \\
\hline Total & 1.7085 & 1.9203 & 1.8593 \\
\hline
\end{tabular}


2014
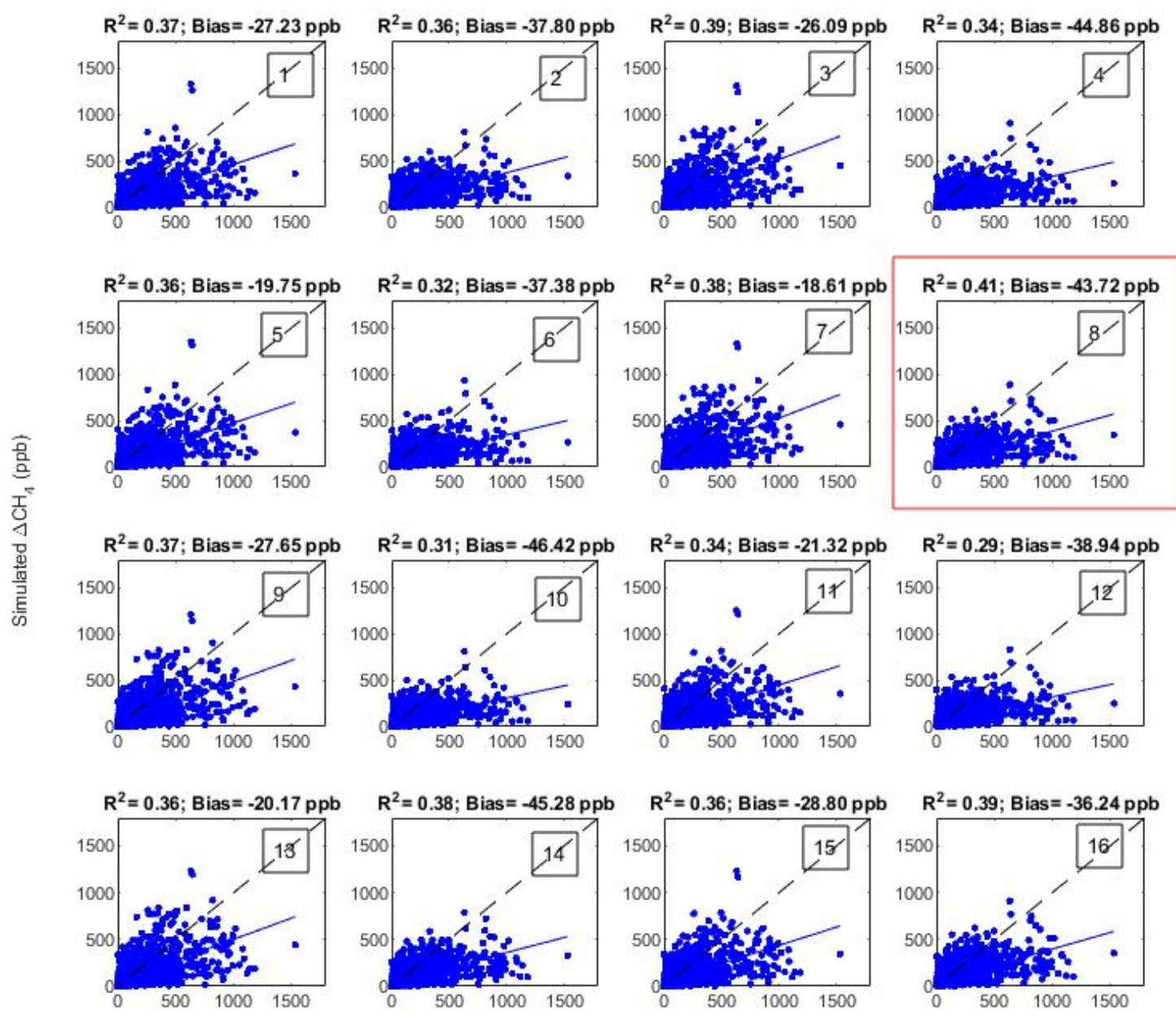

Obs $\Delta \mathrm{CH}_{4}(\mathrm{ppb})$ 

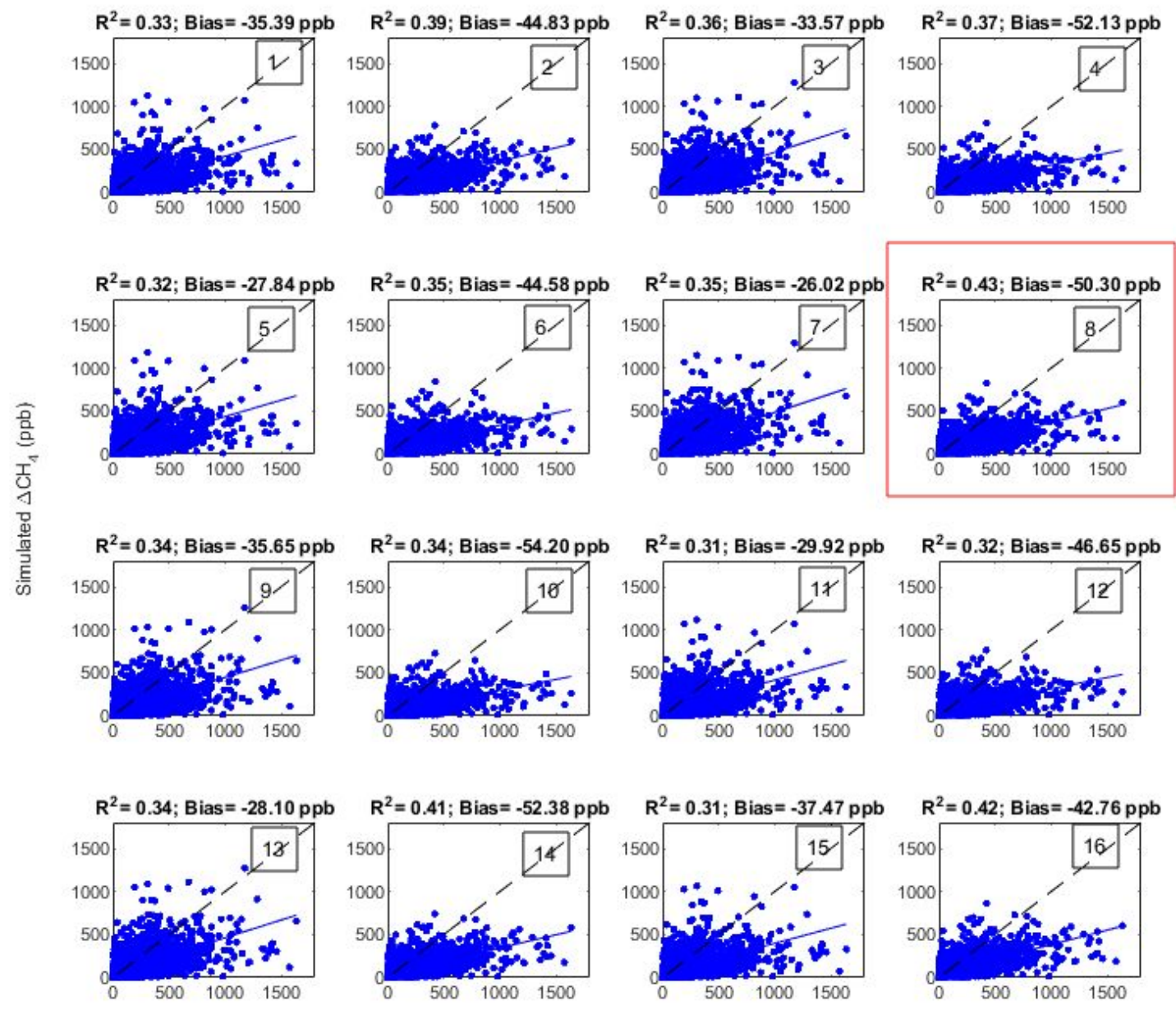

Obs $\Delta \mathrm{CH}_{4}$ (ppb) 

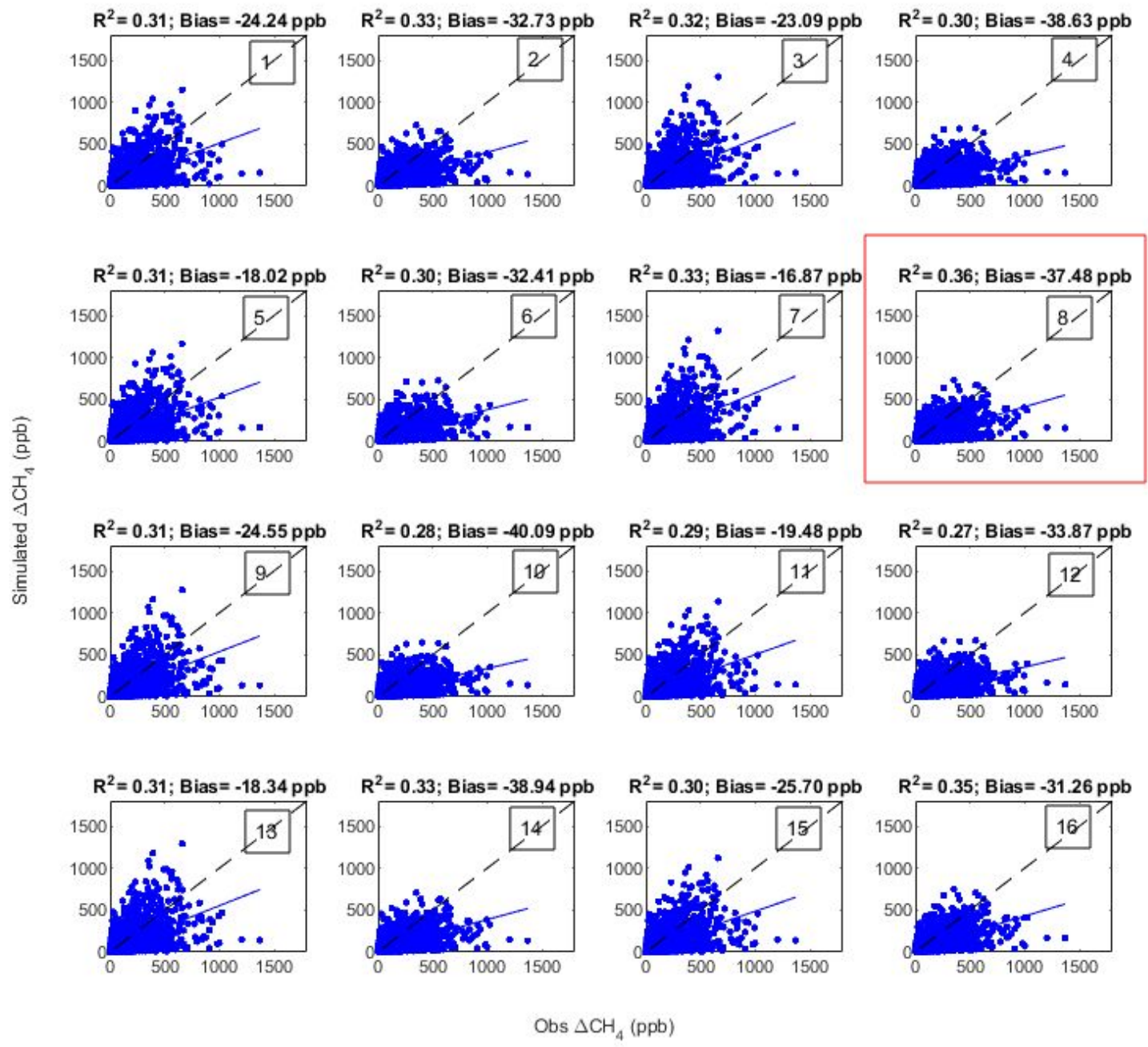

Figure S-6: Comparisons of measured and simulated $\mathrm{CH}_{4}$ mixing ratios during 2014-2016 based on CALGEM, EPA-GHGI, and 14 different hybrid inventories listed in Table S5. The coefficient of determination $\left(\mathrm{R}^{2}\right)$ and mean biases are shown. Comparison \#8 corresponding to the highest

$\mathrm{R}^{2}$ is chosen as the one prior inventory to be used in the inversion estimates. 


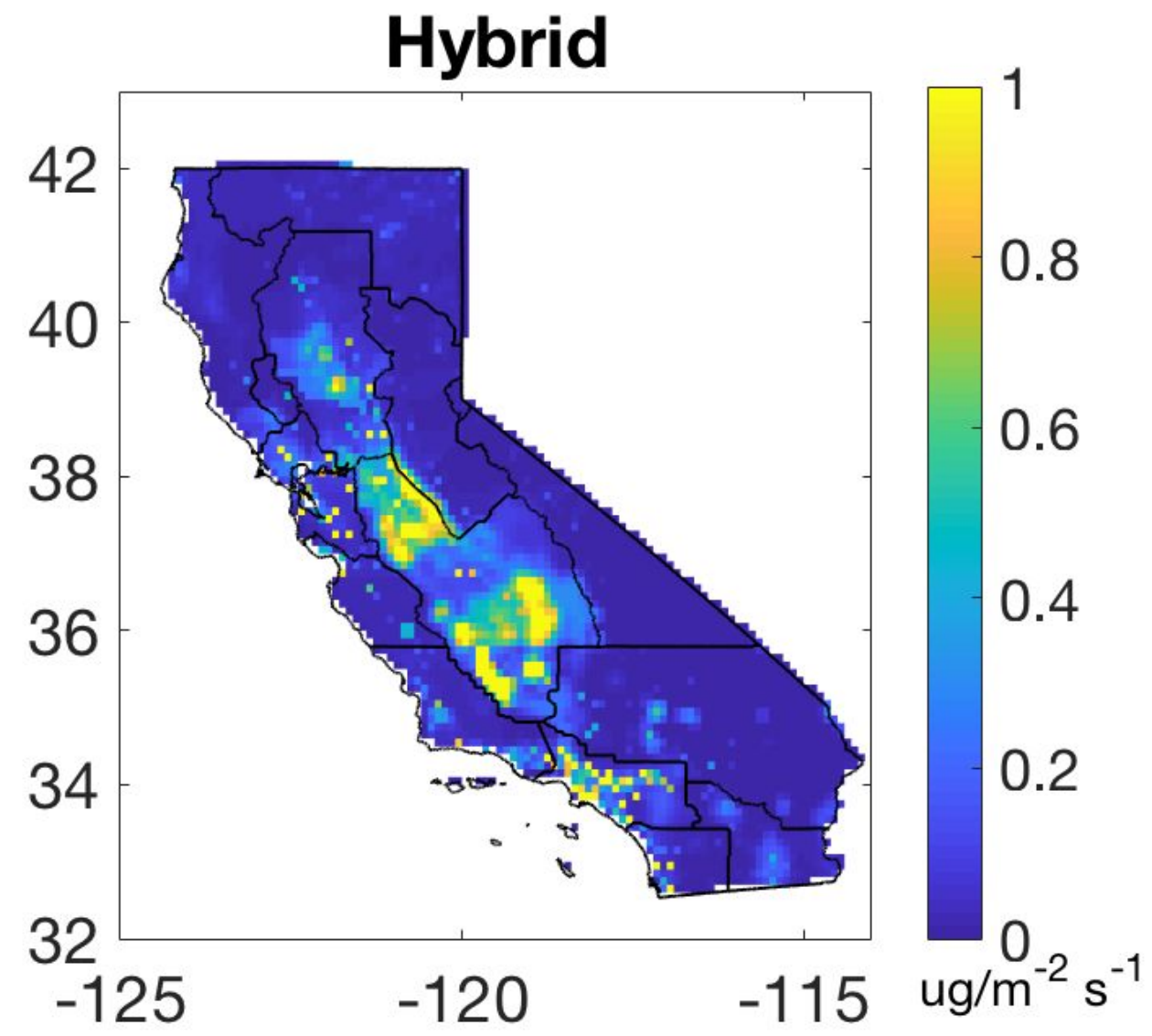

Figure S-7: The map of the hybrid inventory selected in the study, among 14 new cases shown in Table S-8. 


\section{Posterior estimates}

Table S-10: Description of six scenarios of multi-platform inversions in the study

\begin{tabular}{|c|c|c|c|}
\hline Setup & Type name & Inversion case & Description \\
\hline $\begin{array}{c}\text { CARB GHG } \\
\text { Network }\end{array}$ & $\begin{array}{l}\text { CARB } \\
\text { towers }\end{array}$ & $\begin{array}{l}2014 \text { Inv } \\
2015 \text { Inv } \\
2016 \text { Inv }\end{array}$ & $\begin{array}{l}\text { Use hourly-measurements from the CARB } \\
\text { Statewide GHG monitoring network for 2014- } \\
2016 \text {, respectively. We consider them as the } \\
\text { base cases. }\end{array}$ \\
\hline $\begin{array}{c}\text { CARB GHG } \\
\text { Network } \\
+ \\
\text { Megacities Carbon } \\
\text { Project (MCP) } \\
\text { Network } \\
\end{array}$ & $\begin{array}{l}\text { CARB } \\
\text { towers }+ \\
\text { MCP } \\
\text { towers }\end{array}$ & $\begin{array}{l}\text { 2015_Inv_urban } \\
\text { 2016_Inv_urban }\end{array}$ & $\begin{array}{l}\text { Combine hourly-measurements from the } \\
\text { CARB Statewide GHG monitoring network } \\
\text { as well as the Megacities Carbon Project } \\
\text { (MCP) for } 2015 \text { to } 2016 \text {, respectively. }\end{array}$ \\
\hline $\begin{array}{c}\text { CARB GHG } \\
\begin{array}{c}\text { Network } \\
+\end{array} \\
\text { NASA AJAX } \\
\text { Flights }\end{array}$ & $\begin{array}{l}\text { CARB } \\
\text { towers }+ \\
\text { AJAX } \\
\text { flights }\end{array}$ & 2014_Inv_flight & $\begin{array}{l}\text { Combine hourly-measurements from the } \\
\text { CARB Statewide GHG monitoring network } \\
\text { for } 2014 \text { and six aircraft measurements for } \\
\text { July-November } 2014 \text {. }\end{array}$ \\
\hline
\end{tabular}


Table S-11: Statistical variables ( $\mathrm{R}^{2}$ and the mean biases) between the observed $\mathrm{CH}_{4}$ mixing ratios (in the 3-hour intervals) from the multiplatform and the corresponding simulations using the prior and the posterior estimates, combining different inversion cases in the study.

\begin{tabular}{|l|l|l|l|l|l|l|}
\hline \multirow{2}{*}{$\mathrm{R}^{2}$} & \multicolumn{2}{|l|}{ CALGEM } & \multicolumn{2}{l|}{ EPA-GHGI } & Hybrid \\
\cline { 2 - 7 } & Prior & Posterior & Prior & Posterior & Prior & Posterior \\
\hline CARB towers & $0.31-0.37$ & $0.33-0.38$ & $0.33-0.39$ & $0.35-0.42$ & $0.36-0.43$ & $0.35-0.43$ \\
\hline $\begin{array}{l}\text { CARB towers } \\
+ \text { MCP towers }\end{array}$ & $0.17-0.20$ & $0.28-0.31$ & $0.11-0.19$ & $0.27-0.33$ & $0.15-0.24$ & $0.27-0.33$ \\
\hline $\begin{array}{l}\text { CARB towers } \\
+ \text { AJAX Flight }\end{array}$ & 0.31 & 0.33 & 0.30 & 0.32 & 0.33 & 0.33 \\
\hline
\end{tabular}

\begin{tabular}{|c|c|c|c|c|c|c|}
\hline \multirow{2}{*}{$\begin{array}{ll}\text { Mean } & \text { Bias } \\
(\mathrm{ppb}) & \end{array}$} & \multicolumn{2}{|c|}{ CALGEM } & \multicolumn{2}{|c|}{ EPA-GHGI } & \multicolumn{2}{|l|}{ Hybrid } \\
\hline & Prior & Posterior & Prior & Posterior & Prior & Posterior \\
\hline CARB towers & $\begin{array}{l}(-35.39)^{-} \\
(-24.24) \\
\end{array}$ & $\begin{array}{l}(-21.12)^{-} \\
(1.18) \\
\end{array}$ & \begin{tabular}{|l}
$(-44.83)^{-}$ \\
$(-32.73)$ \\
\end{tabular} & $\begin{array}{l}(-24.83)^{-} \\
(-14.75) \\
\end{array}$ & $\begin{array}{l}(-50.30)^{-} \\
(-37.48) \\
\end{array}$ & $\begin{array}{l}(-32.45)^{-} \\
(-15.21)\end{array}$ \\
\hline $\begin{array}{l}\text { CARB towers } \\
+ \text { MCP towers }\end{array}$ & $\begin{array}{l}(-77.88)- \\
(-74.76)\end{array}$ & $\begin{array}{l}(-23.52)- \\
(-22.05)\end{array}$ & $\begin{array}{l}(-98.70)^{-} \\
(-86.68)\end{array}$ & $\begin{array}{l}(-30.65)- \\
(-26.16)\end{array}$ & $\begin{array}{l}(-99.38)- \\
(-89.47)\end{array}$ & $\begin{array}{l}(-29.95)- \\
(-26.35)\end{array}$ \\
\hline $\begin{array}{l}\text { CARB towers } \\
+ \text { AJAX Flight } \\
\end{array}$ & -35.06 & -13.02 & -45.87 & -23.57 & -51.31 & -24.75 \\
\hline
\end{tabular}


Table S-12: Statewide $\mathrm{CH}_{4}$ emission estimates for 2014-2016 from inversions regarding to the multiplatform, and the associated prior information

\begin{tabular}{|l|l|l|l|l|l|l|l|}
\hline \multirow{2}{*}{ Type } & \multicolumn{2}{|l|}{ CALGEM (Tg/yr) } & \multicolumn{2}{l|}{ EPA-GHGI (Tg/yr) } & \multicolumn{2}{l|}{ Hybrid (Tg/yr) } & \multicolumn{2}{l|}{$\begin{array}{l}\text { Overall } \\
\text { (Tg/yr) }\end{array}$} \\
\cline { 2 - 8 } & Prior & Posterior & Prior & Posterior & Prior & Posterior & Posterior \\
\hline CARB towers & 1.71 & $1.83 \pm 0.09$ & 1.92 & $2.05 \pm 0.06$ & 1.86 & $2.04 \pm 0.10$ & $1.97 \pm 0.21$ \\
\hline $\begin{array}{l}\text { CARB towers }+ \\
\text { MCP towers }\end{array}$ & 1.71 & $2.03 \pm 0.07$ & 1.92 & $2.13 \pm 0.27$ & 1.86 & $2.24 \pm 0.07$ & $2.13 \pm 0.24$ \\
\hline $\begin{array}{l}\text { CARB towers }+ \\
\text { AJAX Flights }\end{array}$ & 1.71 & $1.99 \pm 0.11$ & 1.92 & $2.15 \pm 0.06$ & 1.86 & $2.18 \pm 0.07$ & $2.11 \pm 0.19$ \\
\hline Overall & 1.71 & $1.93 \pm 0.20$ & 1.92 & $2.09 \pm 0.19$ & 1.86 & $2.13 \pm 0.20$ & $2.05 \pm 0.26$ \\
\hline
\end{tabular}


Posterior - Prior $_{\text {CALGeM }}$

Inv 2014

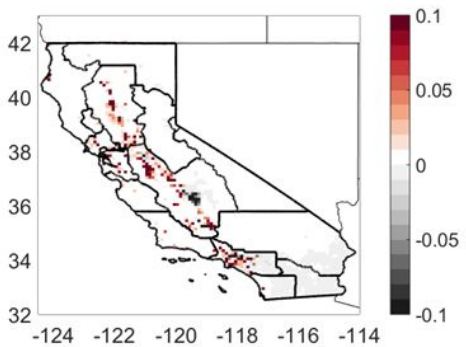

Inv 2014 flight

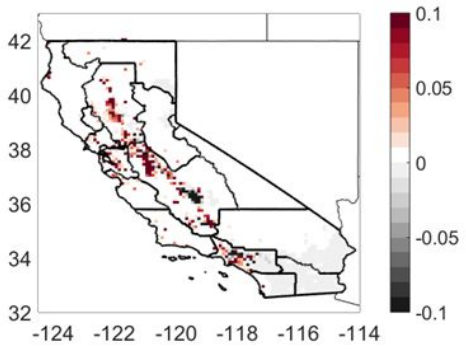

Inv 2015

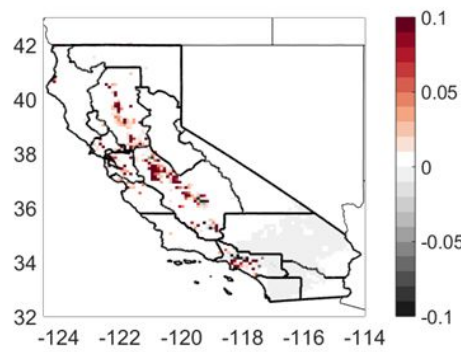

Inv 2015 urban

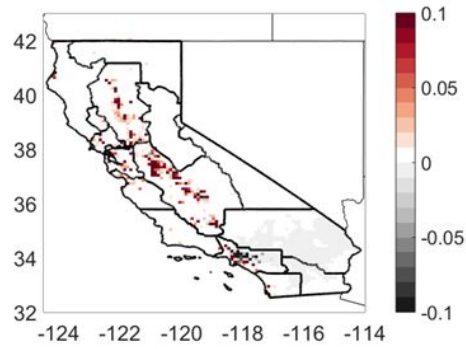

Inv 2016

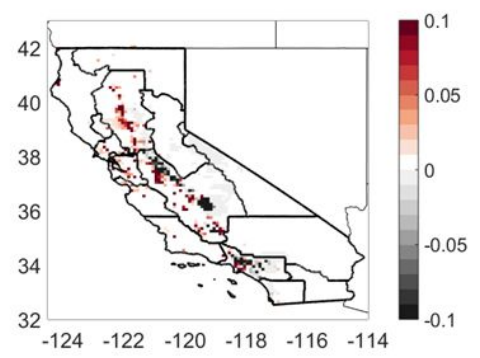

Inv 2016 urban

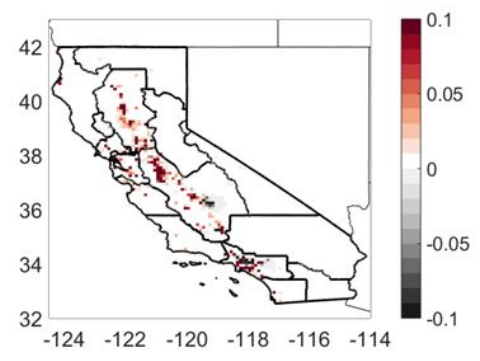

Posterior - Prior ${ }_{\text {EPAGHGI }}$

Inv_2014

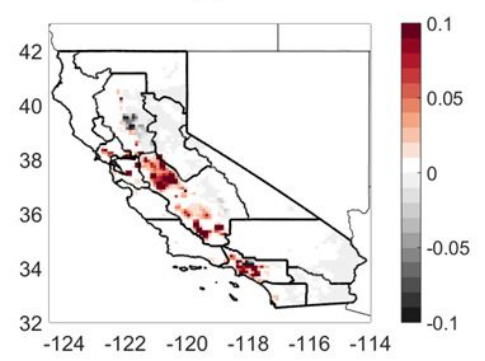

Inv_2014_flight

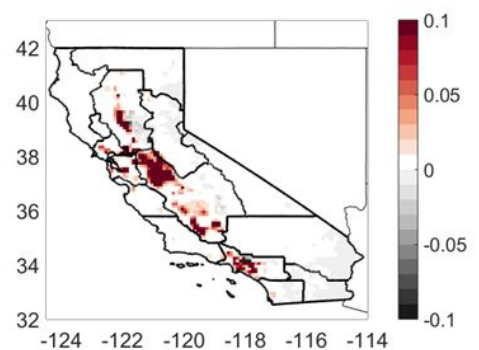

Inv_2015

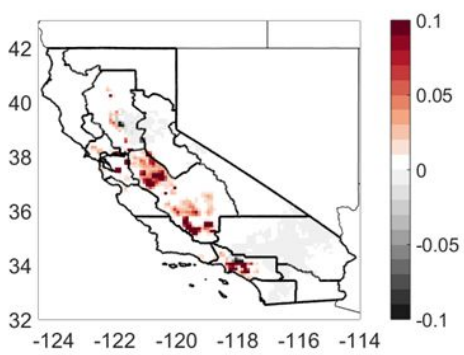

Inv_2015_urban

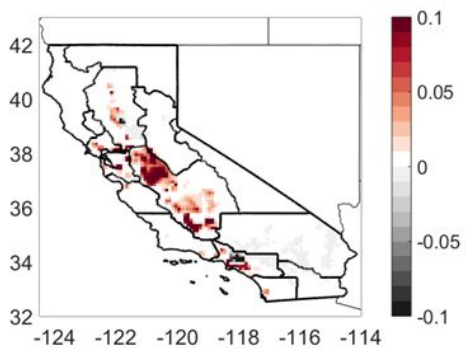

Inv_2016

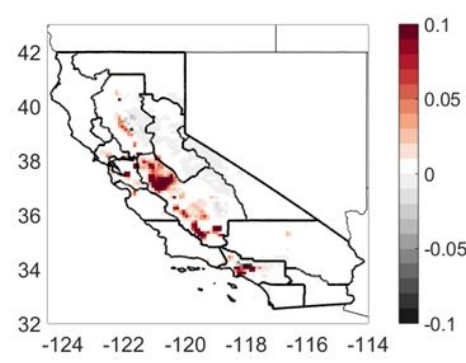

Inv_2016_urban

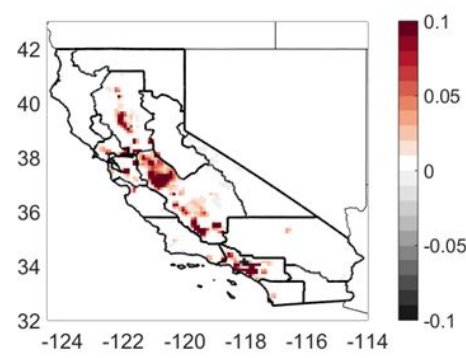


Posterior - Prior $_{\text {Hybrid }}$
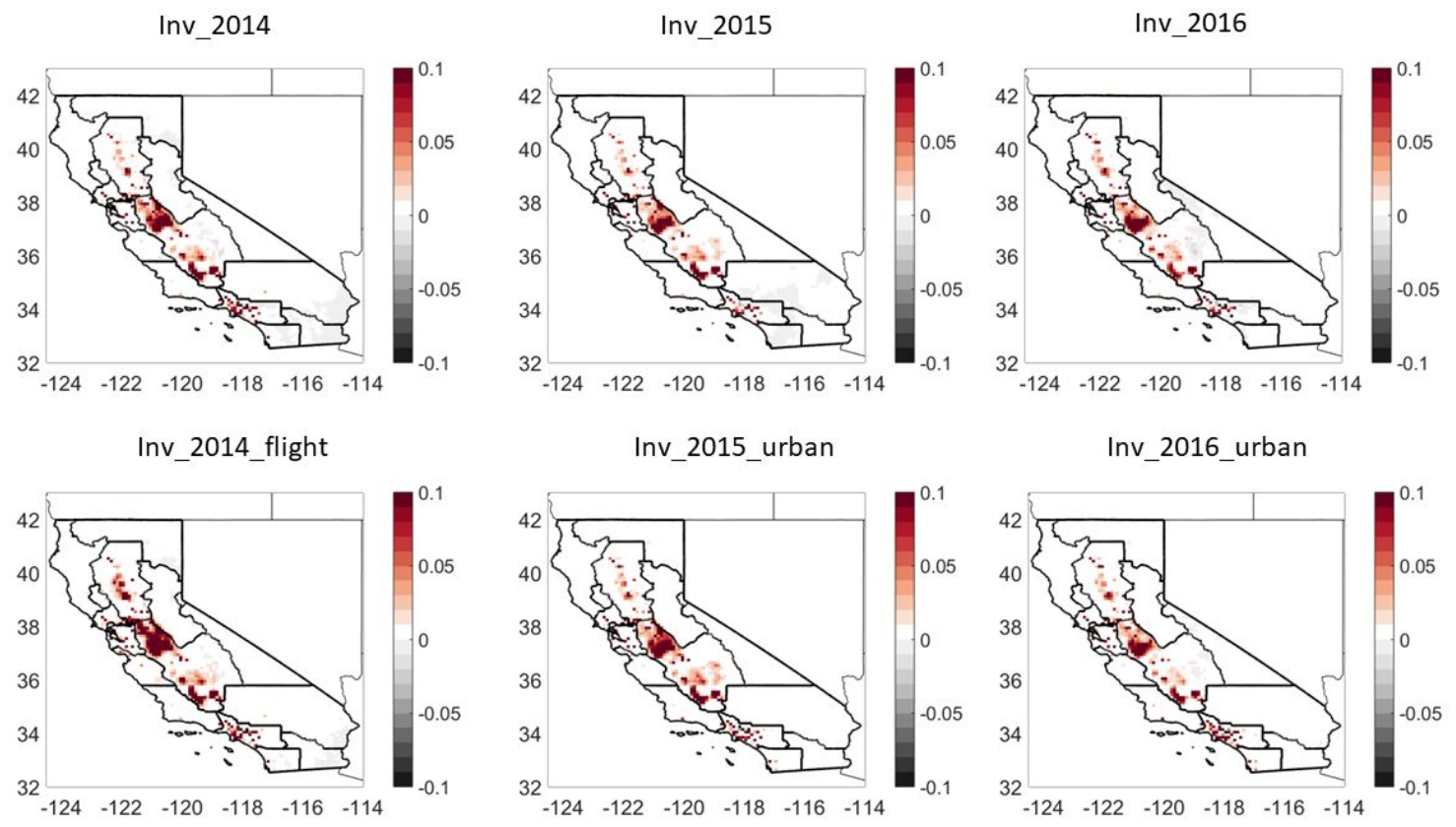

Figure S-8. Maps of differences at the spatial distribution of $\mathrm{CH}_{4}$ emission $\left(\mu \mathrm{g} \mathrm{m}^{-2} \mathrm{~s}^{-1}\right.$.) between the prior and posterior estimates during 2014-2016. (Spatial resolution is 0.1 degree) 


\section{CALGEM}
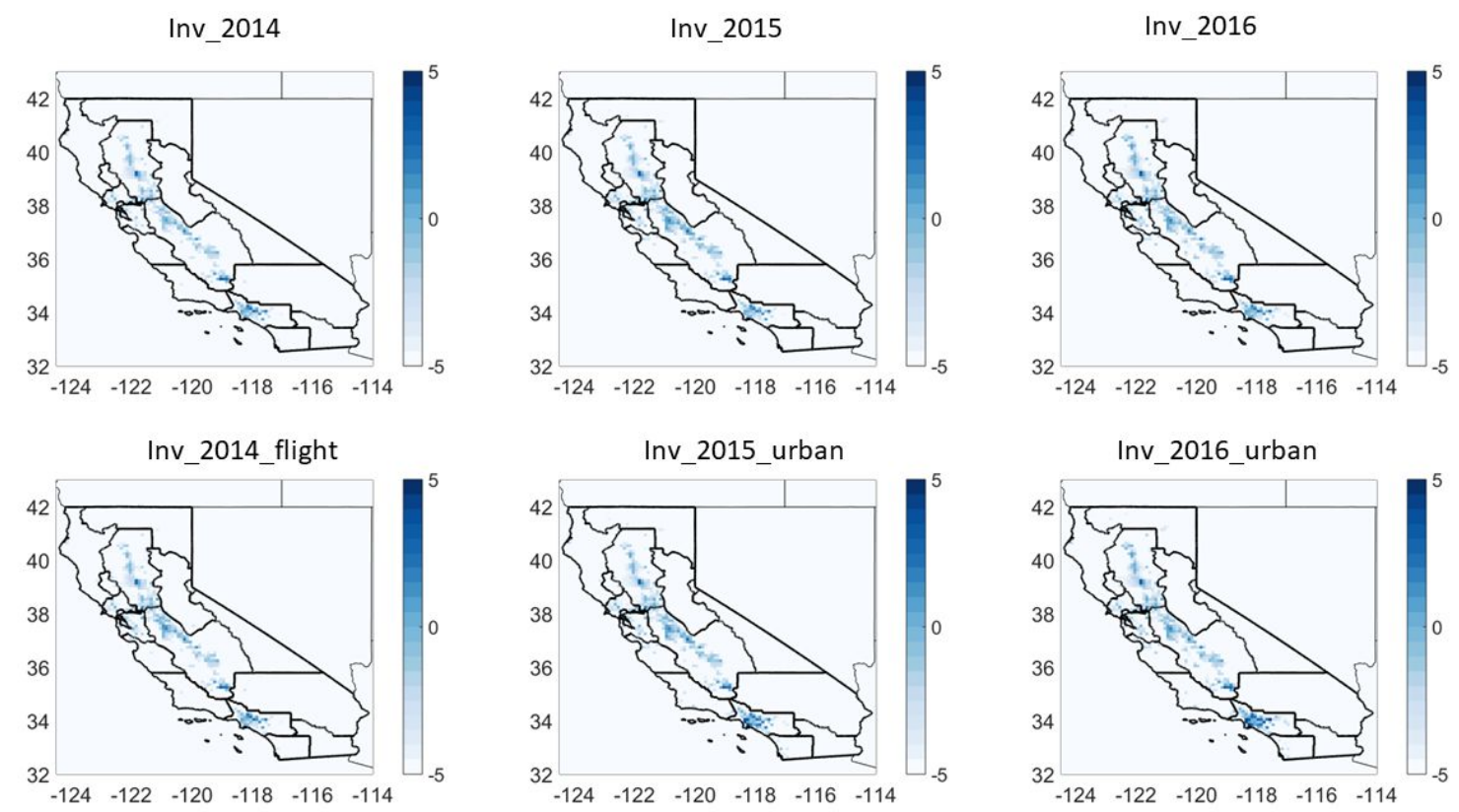

\section{EPAGHGI}
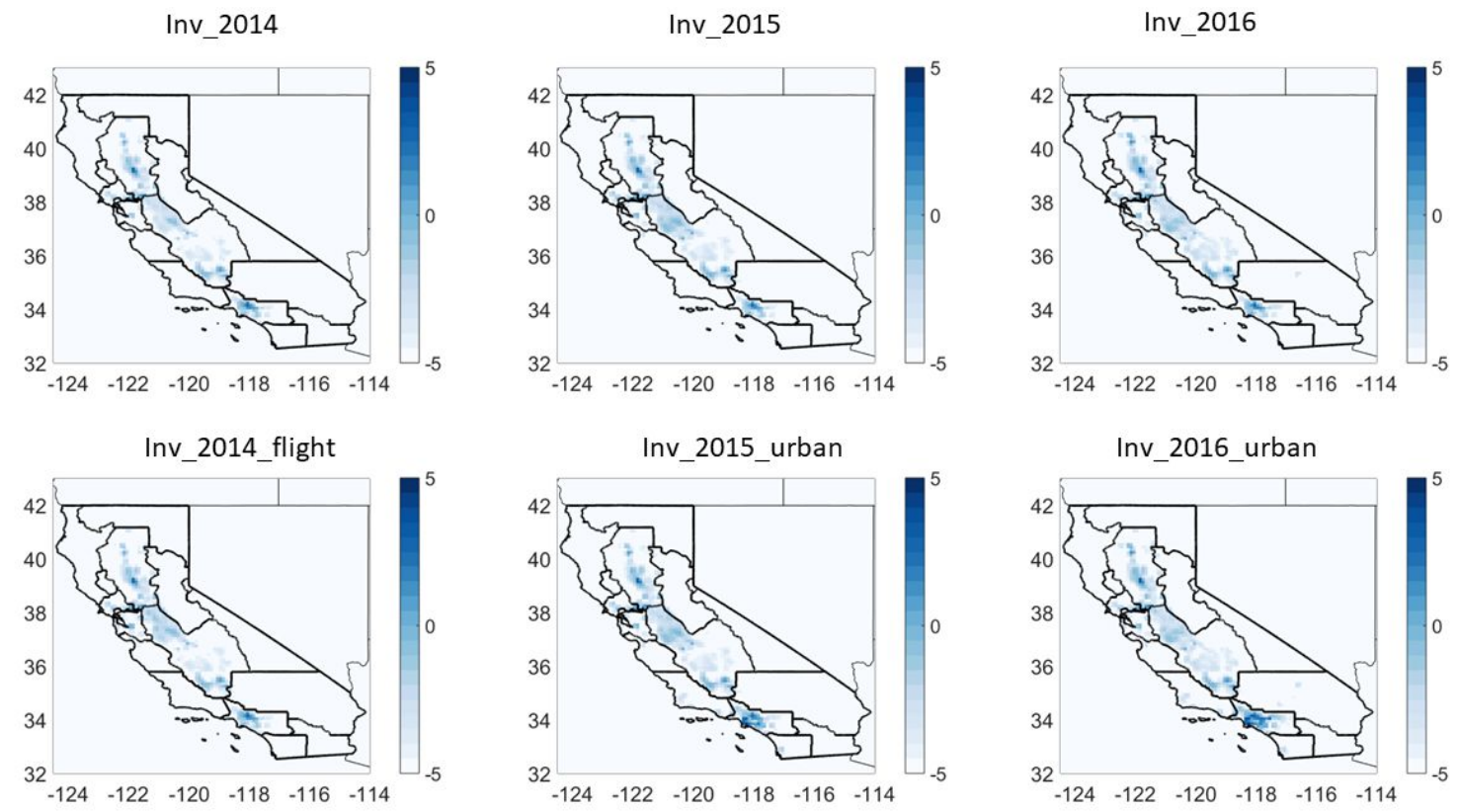


\section{Hybrid}
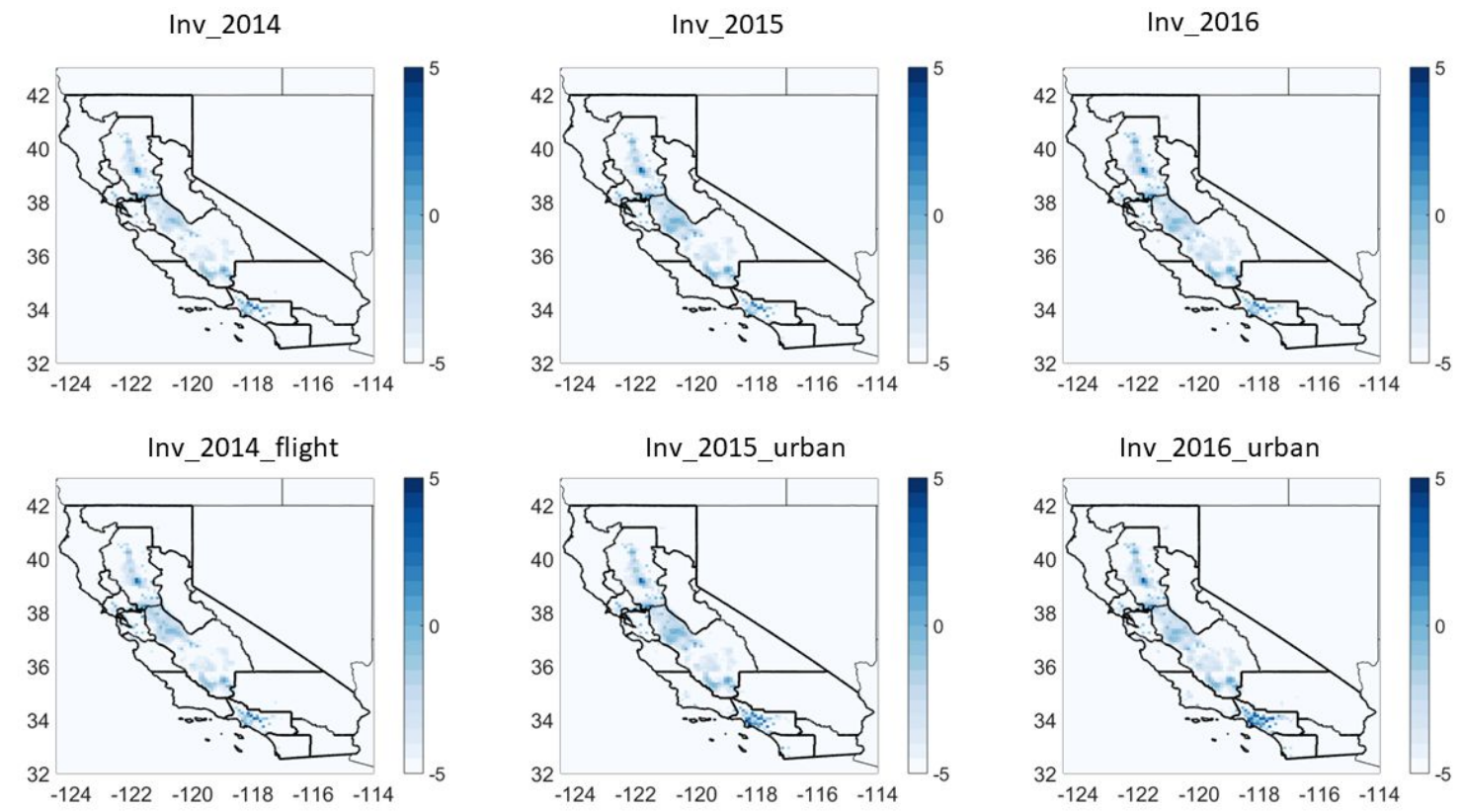

Figure S-9. The statewide maps (log scale) of the Fisher information matrix criterion (the diagonal values) during 2014-2016. The spatial resolution is 0.1 degree. 

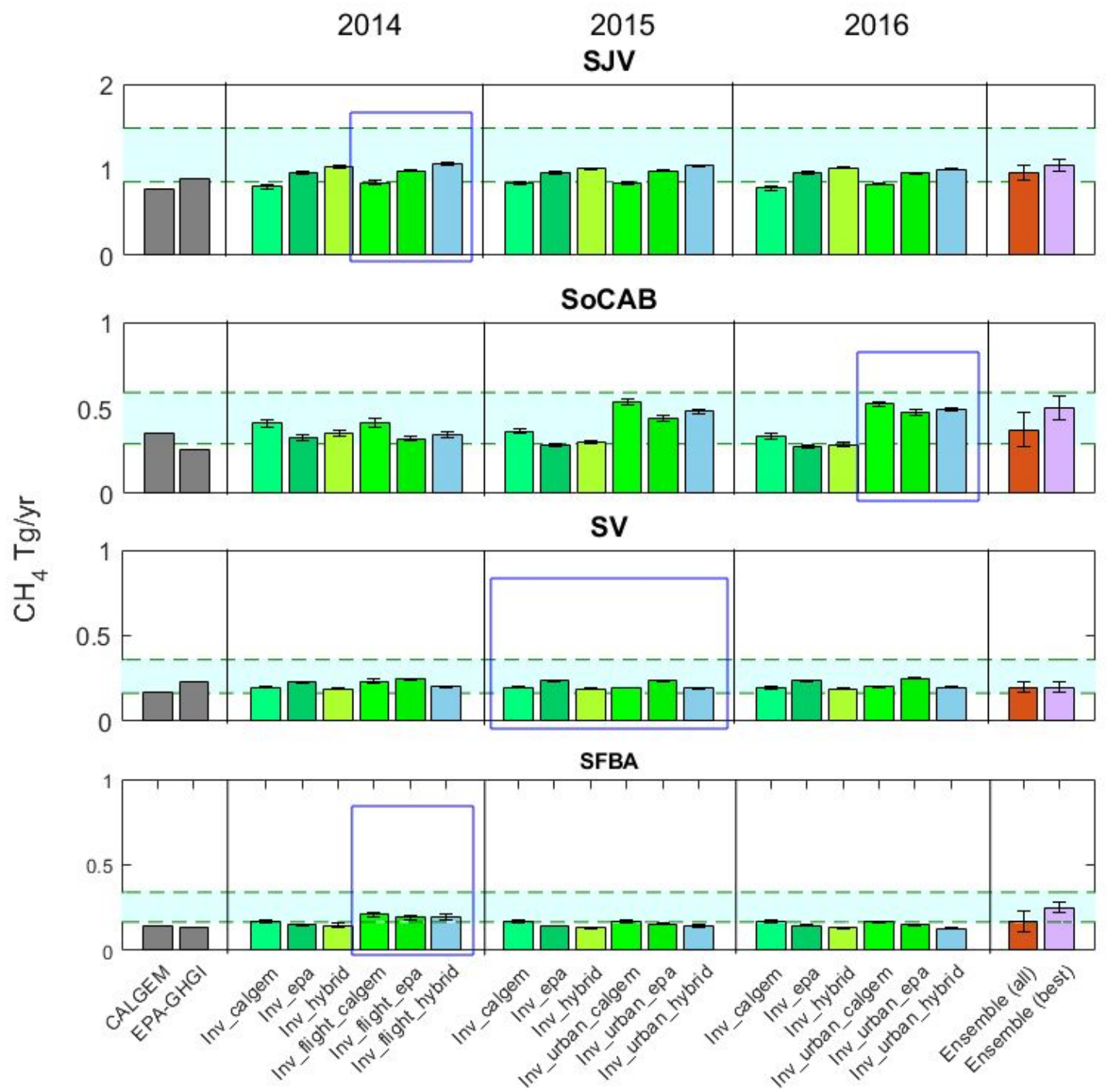

Figure S-10: Sub-regional $\mathrm{CH}_{4}$ emission estimates from multiple inversion cases in the study, compared with two gridded bottom-up inventories used in the study. The shaded region in lightgreen represents previous top-down studies. Cases marked by the light-blue boxes have the best footprint coverage in the corresponding sub-regions (see Table S-6). Inversions in the study include estimates of the exceptional gas leak event at Aliso Canyon. The uncertainty calculated in each inversion case is structured in 1-sigma, and the uncertainties of ensemble results are presented at $95 \%$ confidence (2-sigma). 


\section{$\underline{\text { Sectoral analysis for San Joaquin Valley (SJV) }}$}

We estimated two major $\mathrm{CH}_{4}$ sources in SJV and shown the results in Table S-13.

Table S-13: Sectoral estimates of $\mathrm{CH}_{4}$ emissions in SJV

\begin{tabular}{|c|c|c|c|c|c|c|}
\hline & \multicolumn{2}{|c|}{ Prior } & \multicolumn{4}{c|}{ Posterior } \\
\hline & CALGEM & EPA-GHGI & Inv_CALGEM & Inv_EPAGHGI & Inv_hybrid & Ensemble \\
\hline Dairy & 0.66 & 0.28 & $0.70 \pm 0.06$ & $0.30 \pm 0.03$ & $0.33 \pm 0.02$ & $0.44 \pm 0.36$ \\
\hline $\begin{array}{c}\text { ONG } \\
\text { production }\end{array}$ & 0.05 & 0.27 & $0.07 \pm 0.02$ & $0.30 \pm 0.03$ & $0.31 \pm 0.02$ & $0.22 \pm 0.23$ \\
\hline
\end{tabular}

\section{$\underline{\text { Temporal variation analysis }}$}

To analyze the monthly variability of $\mathrm{CH}_{4}$ emissions, we also conducted the monthly-based inversions (Figure S-14), in addition to the annual inversions conducted in the study (Figure S13). The monthly inversions used a similar setup as the annual inversion scenario, and relied on the corresponding measurements for each month separately.

According to literature, some anthropogenic $\mathrm{CH}_{4}$ sources have sufficient seasonal variabilities, such as livestock, landfill, rice cultivation, and natural gas demand ${ }^{31,37-39}$. In our posterior estimates, the SV region showed a clear enhancement in the summer months, associated with the rice-growing season. The monthly trends are relatively unclear in the other three regions (SFBA, SoCAB, and SJV) which have a larger variety of $\mathrm{CH} 4$ sources encompassed in the regions with varied temporal behavior. The 3-year average emission trends in SJV and SFBA showed slight increases during summer months, which may be due to the dairy sector. These regions also showed some increases during the winter months, which needs further study. On the other hand, California also experienced drought conditions during the 2014-2016 period ${ }^{40}$. Although a large part of the state was in drought conditions in 2016, but there were high precipitations events in northern California during Jan, 2016 ${ }^{41}$. All regions (SJV, SFBA, and SV) in the northern California showed lower $\mathrm{CH}_{4}$ emissions in the first 1-3 months of 2016 when compared to other years, and these were likely influenced by the high precipitation events during the winter months. The data provide general trends and directionality of emissions. However, it must also be noted that since the associated uncertainties is much larger than monthly variability, the study was not able to completely resolve the seasonal/monthly variability analysis of $\mathrm{CH}_{4}$ emissions. Reasons may include:

(1) The density of current tower network may lack the sensitivity to capture the sources which have significant seasonal/monthly variabilities (e.g. we only have one tower in Southern SJV where diary sources are located);

(2) Complicated regional meteorology (e.g. SJV) may result in larger uncertainty of transport model simulations;

(3) Use of static prior inputs (annual average emission rates due to the lack of California-specific seasonal factors for sources) to initialize the inversions would also be a contributing factor;

(4) The current inversion configuration focused on the annual emission scale but not the monthlyspecific inversion setup. 
Lastly, although the posterior results in the study could not resolve the seasonal/monthly variations very well, we consider the uncertainty analysis is conservative enough to handle the valid annual emission budget analysis for the statewide and regional annual $\mathrm{CH}_{4}$ emissions.
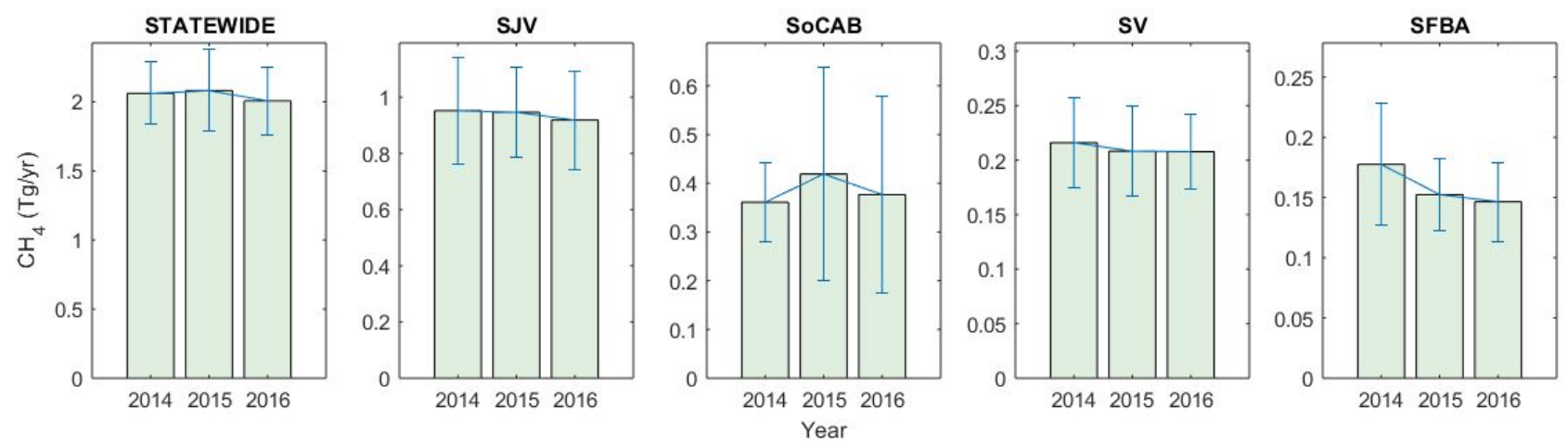

Figure S-11: The posterior ensemble results by year for statewide and four sub-regions. The associated uncertainties are in a $95 \%$ confidence. 

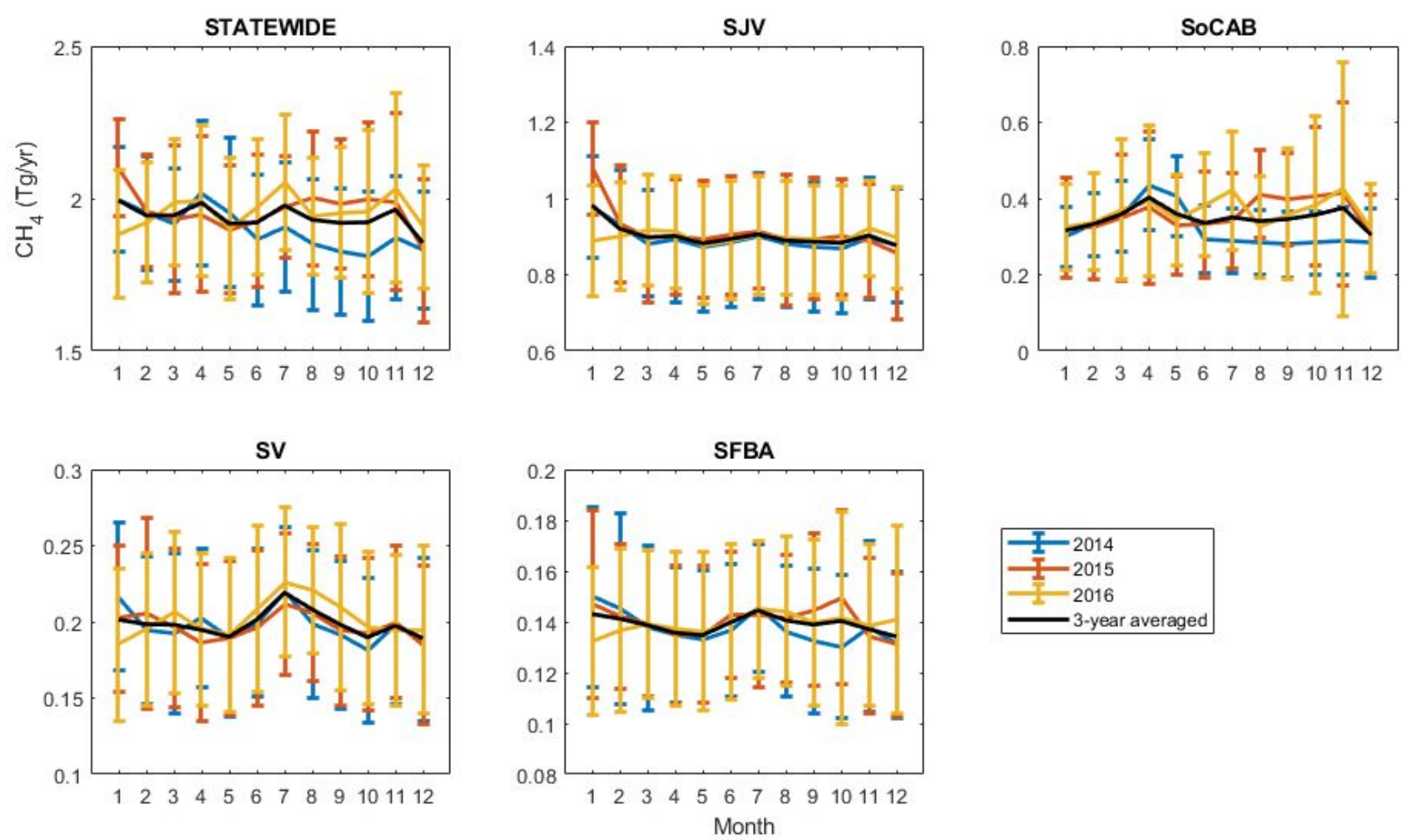

Figure S-12: The posterior ensemble results by month for statewide and four sub-regions. The associated uncertainties are in a $95 \%$ confidence.

\section{$\underline{\text { Next steps }}$}

(a)

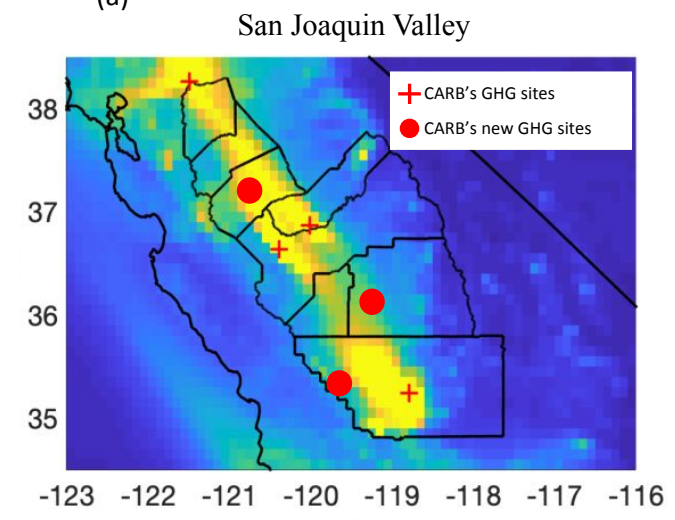

(b)

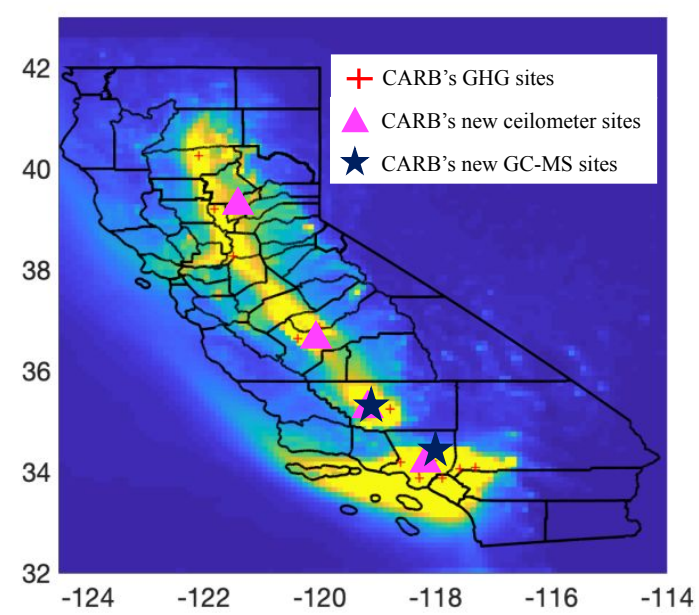

Figure S-13: Map of the on-going CARB additional measurements including (a) GHG monitoring expansion in SJV, and (b) The CARB's Statewide Ceilometer Network and two GCMS sites. 


\section{$\underline{\text { Acknowledgment }}$}

The authors would like to thank California Air Resources Board (CARB) staff who assisted in data collection and inventory interpretation, and providing valuable comments during the review process, and special thanks to Anny Huang, Larry Hunsaker, Toshihiro Kuwayama, Pingkuan Di, Xiaoxi Liu, and Mac McDougall. Funding for AJAX instrumentation and aircraft integration is acknowledged from NASA Ames Research Center Director's funds, and the authors recognize the support and partnership of H211, L.L.C. AJAX data used in this study are available upon request from Laura.Iraci@NASA.gov. T. Tanaka was funded by the NASA Postdoctoral Program. A portion of the research described in this paper was carried out at the Jet Propulsion Laboratory, California Institute of Technology, under contract with the National Aeronautics and Space Administration (NASA). The surface monitoring network in the South Coast Air Basin was established as a partnership between NASA's Jet Propulsion Laboratory and the Scripps Institution of Oceanography for the Megacities Carbon Project. Funding for the Megacities Carbon Project was provided by the National Institute of Standards and Technology (NIST) Greenhouse Gas and Climate Science Measurements Program, NASA, and CARB. MLF acknowledges support from CARB and the California Energy Commission (CEC) Public Interest Environmental Research Program for work at the Lawrence Berkeley National Laboratory, operating under U.S. Department of Energy under Contract No. DE-AC02-05CH11231. We would like to thank several Earth Networks staff, including Clayton Fain and Bill Angel for keeping sites maintained and online and regular status updates, Donnie Bixler and Bryan Biggs for network support, and James Aman for regular quality control checks. We thank the following institutions for providing facilities to host monitoring sites at San Clemente Island (US Navy), University of Southern

California, University of California Irvine, California State University Fullerton, California Institute of Technology, and Canoga Park High School. We are also grateful for Thomas Pongetti and Stanley Sander from NASA's Jet Propulsion Laboratory who assisted us for operating the Mt. Wilson site, and Arlyn Andrews from National Oceanic and Atmospheric Administration (NOAA)'s Earth System Research Laboratory who contributed to the collaborative measurements at the WGC tower. The statements and opinions expressed in this paper are solely the authors' and do not represent the official position of the CARB or other funding agencies. The mention of trade names, products, and organizations does not constitute endorsement or recommendation for use. 


\section{$\underline{\text { Reference }}$}

1. Zhao, C.; Andrews, A. E.; Bianco, L.; Eluszkiewicz, J.; Hirsch, A.; MacDonald, C.; Nehrkorn, T.; Fischer, M. L., Atmospheric inverse estimates of methane emissions from Central California. J. Geophys. Res.: Atmos. 2009, 114 (D16); DOI:10.1029/2008JD011671.

2. Jeong, S.; Hsu, Y.-K.; Andrews, A. E.; Bianco, L.; Vaca, P.; Wilczak, J. M.; Fischer, M. L., A multitower measurement network estimate of California's methane emissions. J. Geophys. Res.: Atmos. 2013, 118 (19), 11,339-11,351.

3. Wecht, K. J.; Jacob, D. J.; Sulprizio, M. P.; Santoni, G. W.; Wofsy, S. C.; Parker, R.; Bösch, H.; Worden, J., Spatially resolving methane emissions in California: constraints from the CalNex aircraft campaign and from present (GOSAT, TES) and future (TROPOMI, geostationary) satellite observations. Atmos. Chem. Phys. 2014, 14 (15), 8173-8184.

4. Jeong, S.; Newman, S.; Zhang, J.; Andrews, A. E.; Bianco, L.; Bagley, J.; Cui, X.; Graven, H.; Kim, J.; Salameh, P.; LaFranchi, B. W.; Priest, C.; Campos-Pineda, M.; Novakovskaia, E.; Sloop, C. D.; Michelsen, H. A.; Bambha, R. P.; Weiss, R. F.; Keeling, R.; Fischer, M. L., Estimating methane emissions in California's urban and rural regions using multitower observations. J. Geophys. Res.: Atmos. 2016, 121 (21), 13,031-13,049.

5. Cui, Y. Y.; Brioude, J.; Angevine, W. M.; Peischl, J.; McKeen, S. A.; Kim, S.-W.; Neuman, J. A.; Henze, D. K.; Bousserez, N.; Fischer, M. L.; Jeong, S.; Michelsen, H. A.; Bambha, R. P.; Liu, Z.; Santoni, G. W.; Daube, B. C.; Kort, E. A.; Frost, G. J.; Ryerson, T. B.; Wofsy, S. C.; Trainer, M., Top-down estimate of methane emissions in California using a mesoscale inverse modeling technique: The San Joaquin Valley. J. Geophys. Res.: Atmos. 2017, 122 (6), 3686-3699. 6. Wunch, D.; Wennberg, P. O.; Toon, G. C.; Keppel-Aleks, G.; Yavin, Y. G., Emissions of greenhouse gases from a North American megacity. Geophys. Res. Lett. 2009, 36 (15); DOI:10.1029/2009GL039825.

7. Wennberg, P. O.; Mui, W.; Wunch, D.; Kort, E. A.; Blake, D. R.; Atlas, E. L.; Santoni, G. W.; Wofsy, S. C.; Diskin, G. S.; Jeong, S.; Fischer, M. L., On the Sources of Methane to the Los Angeles Atmosphere. Environ. Sci. Technol. 2012, 46 (17), 9282-9289.

8. Peischl, J.; Ryerson, T. B.; Brioude, J.; Aikin, K. C.; Andrews, A. E.; Atlas, E.; Blake, D.; Daube, B. C.; de Gouw, J. A.; Dlugokencky, E.; Frost, G. J.; Gentner, D. R.; Gilman, J. B.; Goldstein, A. H.; Harley, R. A.; Holloway, J. S.; Kofler, J.; Kuster, W. C.; Lang, P. M.; Novelli, P. C.; Santoni, G. W.; Trainer, M.; Wofsy, S. C.; Parrish, D. D., Quantifying sources of methane using light alkanes in the Los Angeles basin, California. J. Geophys. Res.: Atmos. 2013, 118 (10), 4974-4990.

9. Wong, K. W.; Fu, D.; Pongetti, T. J.; Newman, S.; Kort, E. A.; Duren, R.; Hsu, Y. K.; Miller, C. E.; Yung, Y. L.; Sander, S. P., Mapping $\mathrm{CH}<\mathrm{sub}>4</$ sub $>$ : $\mathrm{CO}<\operatorname{sub}>2</$ sub $>$ ratios in Los Angeles with CLARS-FTS from Mount Wilson, California. Atmos. Chem. Phys. 2015, 15 (1), 241-252.

10. Cui, Y. Y.; Brioude, J.; McKeen, S. A.; Angevine, W. M.; Kim, S.-W.; Frost, G. J.; Ahmadov, R.; Peischl, J.; Bousserez, N.; Liu, Z.; Ryerson, T. B.; Wofsy, S. C.; Santoni, G. W.; Kort, E. A.; Fischer, M. L.; Trainer, M., Top-down estimate of methane emissions in California using a mesoscale inverse modeling technique: The South Coast Air Basin. J. Geophys. Res.: Atmos. 2015, 120 (13), 6698-6711.

11. Wunch, D.; Toon, G. C.; Hedelius, J. K.; Vizenor, N.; Roehl, C. M.; Saad, K. M.; Blavier, J. F. L.; Blake, D. R.; Wennberg, P. O., Quantifying the loss of processed natural gas within California's South Coast Air Basin using long-term measurements of ethane and methane. Atmos. Chem. Phys. 2016, 16 (22), 14091-14105. 
12. Hedelius, J. K.; Liu, J.; Oda, T.; Maksyutov, S.; Roehl, C. M.; Iraci, L. T.; Podolske, J. R.; Hillyard, P. W.; Liang, J.; Gurney, K. R.; Wunch, D.; Wennberg, P. O., Southern California megacity $\mathrm{CO} 2, \mathrm{CH} 4$, and $\mathrm{CO}$ flux estimates using ground- and space-based remote sensing and a Lagrangian model. Atmos. Chem. Phys. 2018, 18 (22), 16271-16291.

13. Fairley, D.; Fischer, M. L., Top-down methane emissions estimates for the San Francisco Bay Area from 1990 to 2012. Atmos. Environ. 2015, 107, 9-15.

14. Jeong, S.; Cui, X.; Blake, D. R.; Miller, B.; Montzka, S. A.; Andrews, A.; Guha, A.; Martien, P.; Bambha, R. P.; LaFranchi, B.; Michelsen, H. A.; Clements, C. B.; Glaize, P.; Fischer, M. L., Estimating methane emissions from biological and fossil-fuel sources in the San Francisco Bay Area. Geophys. Res. Lett. 2017, 44 (1), 486-495.

15. Johnson, M. S.; Xi, X.; Jeong, S.; Yates, E. L.; Iraci, L. T.; Tanaka, T.; Loewenstein, M.; Tadić, J. M.; Fischer, M. L., Investigating seasonal methane emissions in Northern California using airborne measurements and inverse modeling. J. Geophys. Res.: Atmos 2016, 121 (22), 13753-13767.

16. Hsu, Y.-K.; VanCuren, T.; Park, S.; Jakober, C.; Herner, J.; FitzGibbon, M.; Blake, D. R.; Parrish, D. D., Methane emissions inventory verification in southern California. Atmos. Environ. 2010, 44 (1), 1-7.

17. Kuwayama, T.; Charrier-Klobas, J. G.; Chen, Y.; Vizenor, N. M.; Blake, D. R.; Pongetti, T.; Conley, S. A.; Sander, S. P.; Croes, B.; Herner, J. D., Source Apportionment of Ambient Methane Enhancements in Los Angeles, California, To Evaluate Emission Inventory Estimates. Environ. Sci. Technol. 2019, 53 (6), 2961-2970.

18. Andrews, A. E.; Kofler, J. D.; Trudeau, M. E.; Williams, J. C.; Neff, D. H.; Masarie, K. A.; Chao, D. Y.; Kitzis, D. R.; Novelli, P. C.; Zhao, C. L.; Dlugokencky, E. J.; Lang, P. M.; Crotwell, M. J.; Fischer, M. L.; Parker, M. J.; Lee, J. T.; Baumann, D. D.; Desai, A. R.; Stanier, C. O.; De Wekker, S. F. J.; Wolfe, D. E.; Munger, J. W.; Tans, P. P., CO2, CO, and CH4 measurements from tall towers in the NOAA Earth System Research Laboratory's Global Greenhouse Gas Reference Network: instrumentation, uncertainty analysis, and recommendations for future high-accuracy greenhouse gas monitoring efforts. Atmos. Meas. Tech. 2014, 7 (2), 647687.

19. Brioude, J.; Kim, S.-W.; Angevine, W. M.; Frost, G. J.; Lee, S.-H.; McKeen, S. A.; Trainer, M.; Fehsenfeld, F. C.; Holloway, J. S.; Ryerson, T. B.; Williams, E. J.; Petron, G.; Fast, J. D., Topdown estimate of anthropogenic emission inventories and their interannual variability in Houston using a mesoscale inverse modeling technique. J. Geophys. Res.: Atmos. 2011, 116 (D20); DOI:10.1029/2011JD016215.

20. Mlawer, E. J.; Taubman, S. J.; Brown, P. D.; Iacono, M. J.; Clough, S. A., Radiative transfer for inhomogeneous atmospheres: RRTM, a validated correlated-k model for the longwave. J. Geophys. Res.: Atmos. 1997, 102 (D14), 16663-16682.

21. Dudhia, J., Numerical Study of Convection Observed during the Winter Monsoon Experiment Using a Mesoscale Two-Dimensional Model. J. Atmos. Sci. 1989, 46 (20), 3077-3107.

22. Hong, S.-Y.; Noh, Y.; Dudhia, J., A New Vertical Diffusion Package with an Explicit Treatment of Entrainment Processes. Mon. Weather Rev. 2006, 134 (9), 2318-2341.

23. Pleim, J. E.; Xiu, A., Development of a Land Surface Model. Part II: Data Assimilation. $J$. Appl. Meteorol. 2003, 42 (12), 1811-1822.

24. Xiu, A., and J. E. Pleim, Development of a land surface model. Part I: Application in a mesoscale meteorological model. J. Appl. Meteor. Climatol. 2001, 40, 192-209.

25. Hong, S.-Y.; Lim, J.-O. J., The WRF Single-Moment 6-Class Microphysics Scheme (WSM6). Journal of the Korean Meteorological Society 2006, 42, 129-151. 
26. Kain, J. S., The Kain-Fritsch Convective Parameterization: An Update. $J$ J. Appl. Meteorol. 2004, 43 (1), 170-181.

27. Cui, Y. Y.; Henze, D. K.; Brioude, J.; Angevine, W. M.; Liu, Z.; Bousserez, N.; Guerrette, J.; McKeen, S. A.; Peischl, J.; Yuan, B.; Ryerson, T.; Frost, G.; Trainer, M., Inversion Estimates of Lognormally Distributed Methane Emission Rates From the Haynesville-Bossier Oil and Gas Production Region Using Airborne Measurements. J. Geophys. Res.: Atmos. 2019, 124 (6), 35203531.

28. Hansen, P. C., Rank-Deficient and Discrete Ill-Posed Problems: numerical aspects of linear inversion. SIAM Monographs on Mathematical Modeling and Computation. Society for Industrial Mathematics, Philadelphia, Pennsylvania, USA, 1987.

29. Bagley, J. E.; Jeong, S.; Cui, X.; Newman, S.; Zhang, J.; Priest, C.; Campos-Pineda, M.; Andrews, A. E.; Bianco, L.; Lloyd, M.; Lareau, N.; Clements, C.; Fischer, M. L., Assessment of an atmospheric transport model for annual inverse estimates of California greenhouse gas emissions. J. Geophys. Res.: Atmos. 2017, 122 (3), 1901-1918.

30. de Foy, B.; Cui, Y. Y.; Schauer, J. J.; Janssen, M.; Turner, J. R.; Wiedinmyer, C., Estimating sources of elemental and organic carbon and their temporal emission patterns using a least squares inverse model and hourly measurements from the St. Louis-Midwest supersite. Atmos. Chem. Phys. 2015, 15 (5), 2405-2427.

31. Yadav, V.; Duren, R.; Mueller, K.; Verhulst, K. R.; Nehrkorn, T.; Kim, J.; Weiss, R. F.; Keeling, R.; Sander, S.; Fischer, M. L.; Newman, S.; Falk, M.; Kuwayama, T.; Hopkins, F.; Rafiq, T.; Whetstone, J.; Miller, C., Spatio-temporally Resolved Methane Fluxes From the Los Angeles Megacity. J. Geophys. Res.: Atmos. 2019, 124 (9), 5131-5148.

32. Pesenson, I., Implementation and evaluation of the Heffter Method to calculate the height of the planetary boundary layer above a southern Great Plains site, report, November 30, 2003; (https://escholarship.org/uc/item/6pp1d93m, accessed June 20, 2019).

33. Cui, Y. Y.; Liu, S.; Bai, Z.; Bian, J.; Li, D.; Fan, K.; McKeen, S. A.; Watts, L. A.; Ciciora, S. J.; Gao, R.-S., Religious burning as a potential major source of atmospheric fine aerosols in summertime Lhasa on the Tibetan Plateau. Atmos. Environ. 2018, 181, 186-191.

34. Holzworth, G. C., Mixing Depths, Wind Speeds and Air Pollution Potential for Selected Locations in the United States. J. Appl. Meteorol. 1967, 6 (6), 1039-1044.

35. Bianco, L.; Wilczak, J. M., Convective Boundary Layer Depth: Improved Measurement by Doppler Radar Wind Profiler Using Fuzzy Logic Methods. Journal of Atmospheric and Oceanic Technology 2002, 19 (11), 1745-1758.

36. Ware, J.; Kort, E. A.; DeCola, P.; Duren, R., Aerosol lidar observations of atmospheric mixing in Los Angeles: Climatology and implications for greenhouse gas observations. J. Geophys. Res.: Atmos. 2016, 121 (16), 9862-9878.

37. Arndt, C.; Leytem, A. B.; Hristov, A. N.; Zavala-Araiza, D.; Cativiela, J. P.; Conley, S.; Daube, C.; Faloona, I.; Herndon, S. C., Short-term methane emissions from 2 dairy farms in California estimated by different measurement techniques and US Environmental Protection Agency inventory methodology: A case study. J. Dairy Sci. 2018, 101 (12), 11461-11479.

38. Spokas, K.; Bogner, J.; Chanton, J., A process-based inventory model for landfill $\mathrm{CH}_{4}$ emissions inclusive of seasonal soil microclimate and $\mathrm{CH}_{4}$ oxidation. J. Geophys. Res.: Biogeosci. 2011, 116 (G4); DOI:10.1029/2011JG001741.

39. Knox, S. H.; Matthes, J. H.; Sturtevant, C.; Oikawa, P. Y.; Verfaillie, J.; Baldocchi, D., Biophysical controls on interannual variability in ecosystem-scale $\mathrm{CO}_{2}$ and $\mathrm{CH}_{4}$ exchange in a California rice paddy. J. Geophys. Res.: Biogeosci. 2016, 121 (3), 978-1001. 
40. Drought area in California. https://commons.wikimedia.org/wiki/File:Drought area in California.svg (accessed June 20, 2019).

41. PRISM Climate Data. http://www.prism.oregonstate.edu/recent/ (accessed June 20, 2019). 